NBER WORKING PAPER SERIES

\title{
STOCK VOLATILITY IN THE NEW MILLENNIUM: HOW WACKY IS NASDAQ?
}

\author{
G. William Schwert \\ Working Paper 8436 \\ http://www.nber.org/papers/w8436 \\ NATIONAL BUREAU OF ECONOMIC RESEARCH \\ 1050 Massachusetts Avenue \\ Cambridge, MA 02138 \\ August 2001
}

The Bradley Policy Research Center, William E. Simon Graduate School of Business Administration, University of Rochester, provided support for this research. This paper was prepared for and presented at the April 2001 Carnegie-Rochester Conference on Public Policy. Comments from the referee, Burton Hollifield, and from Rui Albuquerque, Thomas Cooley, Ludger Hentschel, Chris Jones, Charles Plosser, Robert Whaley, and Stanley Zin are gratefully appreciated. The views expressed herein are those of the author and not necessarily those of the National Bureau of Economic Research.

(C) 2001 by G. William Schwert. All rights reserved. Short sections of text, not to exceed two paragraphs, may be quoted without explicit permission provided that full credit, including $(\mathcal{C}$ notice, is given to the source. 
Stock Volatility in the New Millennium: How Wacky Is Nasdaq?

G. William Schwert

NBER Working Paper No. 8436

August 2001

JEL No. G14, G12, G18

\begin{abstract}
$\underline{\text { ABSTRACT }}$
The recent volatility of stock prices has caused many people to conclude that investors have become irrational in valuing at least some stocks. This paper investigates the behavior of the volatility of stocks on the Nasdaq, which tend to be smaller companies with more growth options, in relation to the more seasoned issues reflected in the Standard \& Poor's 500 portfolio. It also analyzes the relation of the unusual Nasdaq volatility to the hot IPO market in 1998 and 1999. The factor that seems to explain unusual volatility best is technology, not firm size or the immaturity of the firm.
\end{abstract}

G. William Schwert

Graduate School of Business Administration

University of Rochester

Rochester, NY 14627

and NBER

Schwert@schwert.ssb.rochester.edu 


\section{Introduction}

The recent behavior of the stock market has been highly unusual in many ways. The stock prices of technology firms have fluctuated wildly at times when more traditional industrial firms have been relatively stable. The after-market performance of many initial public offerings (IPOs) has also been dramatic, with large positive returns followed later by equally large declines. The goal of this paper is to investigate the characteristics of this recent market behavior as a first step in understanding what has occurred.

The focus in this paper will be to identify the sectors of the market that have behaved unusually. In some ways, this motivation is similar to the recent paper by Campbell, Lettau, Malkiel, and Xu (2001), who find that firm-specific (idiosyncratic) volatility rose steadily from 1962-97, even though market and industry volatility did not. My focus, however, will be on the data since 1997, where the most unusual behavior has occurred.

Figure 1a shows the rolling 21-day standard deviation of returns to the Standard \& Poor's (S\&P) composite portfolio and to the Nasdaq composite portfolio from January 1973 through July 25,2001 , both adjusted to an annual rate by multiplying by the square root of the number of trading days in the year, 253,

$$
\sigma\left(\mathrm{R}_{\mathrm{t}}\right)=\left[253 \sum_{\mathrm{k}=1}^{21}\left(\mathrm{R}_{\mathrm{t}-\mathrm{k}}-\mu\right)^{2} / 20\right]^{1 / 2}
$$

where $\mu$ is the sample mean over the same 21 -day window. ${ }^{1}$ Figure $1 \mathrm{~b}$ shows the ratio of the standard deviation of the Nasdaq portfolio to the standard deviation of the S\&P portfolio. These graphs clearly show that the Nasdaq portfolio has become unusually volatile compared with the

\footnotetext{
${ }^{1}$ French and Roll (1986) show that weekend volatility for portfolio returns is approximately the same as any other trading day, and since daily returns are not highly autocorrelated, an estimate of the variance of annual returns is just the number of trading days in the year times the variance of a daily return.
} 
S\&P portfolio since mid-1999. There was also an episode during the last half of 1995 when the Nasdaq portfolio was unusually volatile relative to the S\&P portfolio, but the relative level of these volatility indexes remained stable from 1996 through mid-1999.

The volatility of the S\&P portfolios rose in mid-1998 at the time of the Japanese and Russian financial crises, but it returned to more normal levels by early 1999. There have been brief increases in S\&P volatility in early and late 2000 , but nothing compared with the rise in Nasdaq volatility. Given that some of the large technology firms that influence Nasdaq volatility are also included in the S\&P portfolio (including Cisco, Microsoft, Intel, and Oracle which comprised over $17 \%$ of the index in November 2000 ), it is surprising that S\&P volatility has not increased more.

What kinds of factors could lead to uncertainty in one sector of the market? Some might point to a bubble in the stock prices of technology-related growth stocks that burst. It is not unusual to find large increases in volatility following big drops in prices. French, Schwert, and Stambaugh (1987), Schwert (1989a), and Pagan and Schwert (1990) were among the early papers showing that this effect is broad and pervasive at the market level.

The association between price drops and volatility is not necessarily evidence that an irrational bubble has burst. There has been much recent discussion of an economic slowdown. To the extent that the boom in the economy in recent years is concentrated in the technology sector, it would not be surprising if negative news about future growth could have much stronger effects on technology stocks.

In addition to Nasdaq and technology, I also investigate the association between firm size (equity capitalization) and recent volatility. As a generalization, smaller firms tend to be less 
diversified and younger, so they tend to be riskier than larger firms in the same industry. However, the recent evidence seems to contradict this generalization.

Section 2 analyzes Nasdaq volatility using several alternative methods, including volatility measures implied by the prices of put and call options on the Nasdaq and S\&P portfolios. Section 3 analyzes New York Stock Exchange (NYSE) and American Stock Exchange (Amex) volatility using measures that are similar to the Nasdaq measures in Section 2. Section 4 evaluates some of the plausible explanations for recent volatility. Section 5 concludes and speculates about the implications of this evidence for economic policy.

\section{Nasdaq Volatility}

\section{$\underline{\text { Measuring Historical Volatility }}$}

The simple rolling standard deviation in figure 1a closely approximates the forecast of volatility from the kinds of complicated econometric models that are often used to model conditional volatility. To show this, figure 2 a plots the rolling standard deviation and the estimates of the conditional standard deviation from a GARCH $(1,1)$ model estimated using Nasdaq composite return data from January 1986 through July 25, 2001. ${ }^{2}$ With the exception of the October 1987 stock market crash, where the GARCH measure of volatility is much larger than the rolling standard deviation, the two measures track each other closely. This occurs because the GARCH forecast equation is essentially an exponentially weighted average of past squared returns, with slowly declining weights, and this is similar to the rolling variance, which is a simple average of the last 21 squared returns (abstracting from the negligible effects of subtracting the daily mean return).

\footnotetext{
${ }^{2}$ Bollerslev (1986) developed the GARCH model. Pagan and Schwert (1990) show that this model performs well in comparison with many alternative methods for modeling conditional volatility of stock returns.
} 
Figure $2 \mathrm{~b}$ shows the same comparison of the GARCH standard deviation and the rolling standard deviation for the S\&P composite portfolio. In this case the two estimates are close throughout the entire period, including the 1987 crash.

Table 1 shows the estimates of the $\operatorname{GARCH}(1,1)$ models for the Nasdaq and S\&P composite portfolio returns from January 1986- July 25, 2001. These models show that conditional volatility is persistent over time, as the GARCH parameter $\phi$ is between .75 and .91 . Table 1 also shows estimates where the level of the conditional variance is allowed to differ after 1998. The estimates of the variance shift parameter, $\mathrm{a}_{1}$, are positive and for the Nasdaq portfolio reliably greater than zero, with a robust t-statistic of 3.45. Thus, the estimates of the formal GARCH model for conditional volatility confirm the visual impression from figures 1 and 2 : Nasdaq volatility rose significantly after 1998.

In the remainder of the paper I will focus on graphical analysis of rolling standard deviation estimates.

\section{Implied volatility}

One of the major determinants of the value of put and call options is the volatility that option traders expect for the returns to the underlying stock during the life of the option. Since the other factors that determine option value in the Black-Scholes (1973) model are known and measurable, it has become common practice to invert observed option prices to determine an estimate of the volatility of the underlying stock ("implied volatility"). In fact, the Chicago Board Options Exchange (CBOE) reports implied volatility for the S\&P 100 portfolio (OEX) beginning in 1986 and distributes it using the ticker symbol VIX. It is calculated by taking a weighted average of the implied volatilities of eight OEX calls and puts. The chosen options have an average time to maturity of 30 days. Fleming, Ostdiek, and Whaley (1995) describe and 
analyze this volatility measure. Recently, the CBOE has begun to compute and report a similar measure for the technology dominated Nasdaq 100 portfolio (ticker symbol VXN).

Figure 3a shows the implied volatility indexes for the Standard \& Poor's 100 portfolio (VIX) and for the Nasdaq 100 portfolio (VXN), from 1995 through July 25, 2001. ${ }^{3}$ Figure 3b shows the ratio of VXN to VIX. These graphs confirm the earlier analysis of historical volatility in figure 1. The Nasdaq 100 index has become unusually volatile compared with the S\&P 100 portfolio since mid-1999. There was also an episode during the last half of 1995 when the VXN was unusually high relative to the VIX, but the relative level of these volatility indexes remained stable from 1996 through mid-1999.

\section{Actual versus Implied Volatility}

It is important to remember that actual and implied volatility measure different things. Actual volatility reflects what has happened in the last month, whereas implied volatility reflects what option traders expect will happen over the next month. Therefore, figure 4 plots the ratio of the actual volatility over the next 21 trading days (about one month) to the implied volatility for both the S\&P and the Nasdaq portfolios. In a sense, this is a plot of actual outcomes divided by forecasts. The ratios vary around $100 \%$ indicating that the forecasts are roughly unbiased. The peaks and troughs in figure 4 reflect actual volatility that was much higher or lower than the market forecast, and it is apparent that these forecast errors are strongly correlated across the Nasdaq and S\&P portfolios, since the two lines move together.

\footnotetext{
${ }^{3}$ These data are available at http://www.cboe.com/tools/historical/vix.htm. I have adjusted the officially reported data based on personal communication with Robert Whaley, multiplying the annualized standard deviations by the square root of ratio of the number of trading days divided by the number of calendar days in a year, $(253 / 365)^{1 / 2}$, so that the implied volatility measures are on a similar scale as the historical volatility estimates.
} 
It would be interesting to study the properties of the VIX and VXN as forecasts of market volatility in more depth, but that is beyond the scope of this paper. ${ }^{4}$ For the purposes of the subsequent analysis, I interpret the results in figure 4 as supporting the measures of implied volatility from the $\mathrm{CBOE}$ as indicative that Nasdaq stocks have become much more volatile than the broader S\&P portfolio.

\section{CRSP Nasdaq Portfolios}

To determine why Nasdaq stock volatility has increased recently it is useful to examine the behavior of some different sets of Nasdaq stocks. Figure 5a shows the historical volatility of the value-weighted (VW) and equal-weighted (EW) portfolios of Nasdaq stocks from the Center for Research in Security Prices at the University of Chicago (CRSP) from 1995-2000. Throughout this period, the volatility of the value-weighted portfolio is higher than for the equalweighted portfolio, but this difference is much more noticeable since mid-1998.

Figure $5 \mathrm{~b}$ shows the historical volatility of the CRSP equal-weighted portfolios of Nasdaq stocks sorted by equity capitalization from 1995-2000. Decile 10 represents the largest firms and decile 1 represents the smallest firms. As implied by the higher volatility of the valueweighted portfolio in figure 5a, the large-firm portfolio is much more volatile than the small-firm portfolio. As noted in the introduction, many of the largest Nasdaq stocks are also large compared with NYSE stocks. For example, four large Nasdaq tocks, Cisco, Microsoft, Intel, and Oracle, comprised over 17\% of the value-weighted S\&P composite index in November 2000.

Taken together, the results in figures $5 \mathrm{a}$ and $5 \mathrm{~b}$ show that the unusually high volatility of Nasdaq stocks since mid-1998 is concentrated among the largest Nasdaq stocks. This is somewhat surprising, since historically the small-firm portfolio of NYSE stocks from CRSP has

\footnotetext{
4 Indeed, from correspondence with Robert Whaley, I understand that he is currently working on this topic.
} 
been more volatile than the large-firm portfolio of NYSE stocks. Section 3 will see whether the most recent period has reversed this result.

\section{NYSE and Amex Volatility}

Figure 6a shows the historical volatility of the CRSP value-weighted (VW) and equalweighted (EW) portfolios of NYSE stocks from 1995-2000. Figures 6 (NYSE) and 7 (Amex) are drawn to the same scale as figures $5 \mathrm{a}$ and $5 \mathrm{~b}$ to ease comparison with the results for the Nasdaq portfolios. Since 1996, the volatility of the value-weighted portfolio is higher than for the equal-weighted portfolio, but this difference is much smaller than was true on Nasdaq in figure 5a.

Figure $6 \mathrm{~b}$ shows the historical volatility of the CRSP equal-weighted portfolios of NYSE stocks sorted by equity capitalization from 1995-2000. Decile 10 represents the largest firms and decile 1 represents the smallest firms. As implied by the higher volatility of the value-weighted portfolio in figure $6 \mathrm{a}$, the large-firm portfolio is more volatile than the small-firm portfolio. Again, however, the differences and absolute levels of large firm volatility are much smaller than for the Nasdaq portfolios in figure $5 b$.

Figure 7a shows the historical volatility of the CRSP value-weighted (VW) and equalweighted (EW) portfolios of Amex stocks from 1995-2000. Interestingly, there is not much difference between the volatilities of these portfolios and there has not been a pronounced increase in volatility for either of these Amex portfolios since 1998.

Figure $7 \mathrm{~b}$ shows the historical volatility of the CRSP equal-weighted portfolios of Amex stocks sorted by equity capitalization from 1995-2000. Decile 10 represents the largest firms and decile 1 represents the smallest firms. Unlike Nasdaq and the NYSE, the volatility of the small 
firm decile portfolio is larger than for the large firm portfolio throughout most of the 1995-2000 period, although the differences between the Amex portfolio volatilities are not large.

These figures show that the unusual volatility of large Nasdaq firms since mid-1998 is not a phenomenon of firm size, since it does not show up for Amex stocks and it is considerably muted for NYSE stocks. It is likely that it is the types of Nasdaq firms that have large equity capitalization that explains this result.

\section{Plausible Explanations}

\section{$\underline{\text { Technology Portfolios }}$}

Many of the large firms on Nasdaq, including Amgen, Cisco, Dell, Intel, Microsoft, Oracle, and Sun are identified as technology firms. To see whether the factor explaining unusual behavior is related to Nasdaq or to technology, I analyze the volatility of returns to several technology portfolios available from Datastream. Standard \& Poor's has a Technology Sector index (SPHTEC) that is part of its 500 stock composite index. Nasdaq reports three technology indexes, a Computer index (NASCMPT), a Biotechnology index (NASBIOT), and a Telecommunications index (NASTELC).

Figure 8 shows the historical volatility of the returns to the four technology portfolios from January 1991 - July 25, 2001. As with the earlier graphs, it is apparent that the volatility of these portfolios has increased dramatically since mid-1998. It is interesting that the biotechnology portfolio behaves in much the same way as the computer and telecommunications portfolios, since it is hard to think of similarities in the demand for the products of these firms. Moreover, it is clear that it is not just "Internet fever" that has raised the volatility of these firms. 
Indeed, there is a period in mid-2000 when the volatility of the biotechnology portfolio is noticeably higher than for the computer and telecommunications portfolios.

\section{$\underline{\text { Recent IPOs }}$}

Another aspect of financial markets that has attracted a lot of attention in recent years is the very active IPO market. Figure 9 shows the number of IPOs per month in the US since 1960 and the average initial returns to IPO investors from buying at the IPO price and selling within the next month in the secondary market. These data are available on Jay Ritter's web page ${ }^{5}$ and they are described in Ibbotson, Sindelar and Ritter (1988, 1994). Lowry and Schwert (2001) study and try to explain the dynamics of the apparent IPO cycles. They find that contemporaneous correlated news shocks affect similar IPOs during the multi-month periods when they are being marketed to investors. Benveniste and Spindt (1989) argue that issuing firms and investment banks must share the value of new information learned from informed institutional investors during the pre-IPO marketing process, or else investors will not have incentives to reveal this information. The effects of these shocks, along with the partial adjustment of the IPO price to favorable information that is implied by Benveniste and Spindt, causes average initial IPO returns to be correlated over time.

While the number of IPOs since 1998 has not been unusually high compared with the rest of the 1990s, the average initial return to IPO investors has been very high since mid-1998, averaging about 51\% since July 1998 compared with 18\% for the entire January 1960-May 2001 period. Thus, issuing firms and their investment banks systematically under-valued the stock of IPO firms when setting IPO prices, especially in the last few years.

\footnotetext{
${ }^{5} \mathrm{http} / / /$ bear.cba.ufl.edu/ritter/ipoall.htm.
} 
Ritter (1991) and Loughran and Ritter (1995) argue that the initial returns to IPO investors represent excess enthusiasm by the after-market, rather than under-pricing by investment bankers. They show that returns realized by purchasing recent IPOs in the secondary market are lower than for investments in other more-seasoned stocks. On the other hand, Brav and Gompers (1997) show that the after-market performance of IPO stocks is similar to more seasoned stocks that are matched on firm size and market/book ratios.

Since initial IPO returns have been so high in recent years, and since many of these firms were technology stocks listed on Nasdaq, it is possible that part of the recent rise in Nasdaq volatility is related to (or even caused by) the after-market pricing of IPO stocks. To examine this question, I created three equal-weighted portfolios of stocks that had recently had IPOs using information from the Securities Data Corporation (SDC) database. The "All IPOs" portfolio contains all stocks that had an IPO at least one month before, but no more than one year before, the trading day in question. The exclusion of the first month of after-market trading avoids the problem of after-market price support (which happens in some but not all IPOs) that can distort the volatility of returns. The "Technology IPOs" portfolio includes stocks that are categorized as technology stocks by SDC, and the "Non-technology IPOs" portfolio contains the remainder of the IPO stocks.

Figure 10a shows the historical volatility of the three portfolios of IPO stocks from January 1984 - December 2000. It is surprising to me that the volatility of recent IPO stocks is so low from 1984-mid-1987 and from 1992-1996. For most of the 1984-2001 period, the volatility of the technology portfolio was higher than for the non-technology portfolio, but for most of this period the volatility measures move together closely. 
Figure 10b shows the historical volatility of the three portfolios of IPO stocks from January 1995 - December 2000. It is easier to see from this graph that the volatility of both technology and non-technology IPO stocks rose in mid-1998, but that the volatility of technology stocks remained high in 1999, while non-technology IPO stock volatility returned to lower levels. By mid-2000, the two series again have similar levels. At the end of 2000, the volatility of the non-technology IPO portfolio jumps dramatically.

To put these data into perspective, figure 11 shows the ratio of the volatility of the technology IPO portfolio to the volatility of the value-weighted CRSP Nasdaq portfolio from 1984-2000. It is startling (to me) that this ratio is so close to $100 \%$ since 1993 (the average is $110 \%$ ). Thus, it looks as though the volatility of the prices of recent IPOs is remarkably similar to much larger more seasoned Nasdaq securities.

\section{Big Price Changes}

The analysis thus far has focused on the standard deviation of returns (volatility), but the characteristic of recent Nasdaq behavior that has attracted the most public attention has been the days when large negative returns have occurred (somehow people don't seem to write or talk as much about comparably large positive returns).

Table 2a shows the largest percentage changes in the Nasdaq Composite portfolio between January 1995 and July 2001 in column (1). The corresponding returns to the S\&P 500, S\&P Technology, Nasdaq Computer, and Nasdaq Biotechnology portfolios are in columns (2) through (5). Columns (6) and (8) contain the implied volatilities for the S\&P 100 (VIX) and Nasdaq 100 (VXN) portfolios from option prices on the CBOE. Columns (7) and (9) contain the changes in the implied volatilities from the prior day, $\Delta \mathrm{VIX}$ and $\Delta \mathrm{VXN}$. Table $2 \mathrm{~b}$ contains the same information for the days of the 25 largest percentage increases in the Nasdaq Composite portfolio from 1995-2001. 
Several patterns are clear from these tables. First, the distribution of positive and negative returns is similar; there has been no tendency to have larger negative returns in this period. Second, there is a clustering of large returns of indeterminate sign from mid-October 2000 through April 2001 (13 negative returns and 13 positive returns). Similarly, from early April to early June 2000, there were 6 negative and 6 positive returns on these lists. Thus, about three quarters of the most extreme daily returns during this six-year period occurred in two spans of about eight months in total. These patterns are exactly what one would expect if the volatility of the distribution generating stocks returns was changing and persistent over time.

What were the triggering events for these bursts of volatility? It is always dangerous to use 20-20 hindsight to diagnose the movements of stock prices, since there are potentially many explanations for the factors that cause daily fluctuations. Moreover, simple explanations are often too simple (see, for example, Cutler, Poterba, and Summers (1989)). Nevertheless, I searched Dow Jones News Retrieval (DJNR) for Wall Street Journal stories about Nasdaq prices on the days listed in tables 2a and 2b to see what reporters were saying about the causes of price movements on Nasdaq. The big story about April 3, 2000, the first day of the Spring episode, was the break-down in the negotiations between Microsoft and the Antitrust Division of the Justice Department trying to settle their lawsuit. Bittlingmayer and Hazlett (2000) argue that the Microsoft antitrust lawsuit had substantial common implications for many other firms in the computer industry, so it may not be surprising that broad groups of technology stocks would move together in response to this news.

The Fall 2000 episode centers on the presidential election that dragged on into early December before the uncertainty about its outcome was resolved. However, in both April and October there were many stories about earnings announcements, speculation about changes in Federal Reserve policy, and a variety of stories about macroeconomic indicators that foreshadowed slower growth in future months. Interestingly, stories about lower earnings and slower growth were used by reporters and analysts to explain both large negative and large positive movements in market prices. 
Another pattern that emerges strongly from table $2 \mathrm{a}$ and $2 \mathrm{~b}$ is that volatility and prices moved in opposite directions. When prices fell in table 2a, the implied volatility of the Nasdaq 100 portfolio rose dramatically $(\triangle \mathrm{VXN}$ in column (9)). It is also apparent that for most of the days in table $2 \mathrm{a}$, the performance of the Nasdaq portfolio was driven by technology stocks, since the S\&P 500 return in column (2) was generally much smaller than the returns to the technology portfolios in columns (3) through (5). The implied volatility of the S\&P 100 portfolio also rose on most of these days ( $\Delta$ VIX in column (7)), but the size of the rise was smaller than for $\triangle \mathrm{VXN}$.

The results in table $2 \mathrm{~b}$ for increases in the prices of Nasdaq stocks parallel the results in table 2a. The biggest returns are driven by technology stocks and volatility decreases when prices rise.

As mentioned previously, the opposite contemporaneous movement in volatility and returns is often seen in stock returns and it has been studied extensively. The fact that there are similarly large positive and negative daily returns in tables $2 \mathrm{a}$ and $2 \mathrm{~b}$ suggest that high volatility is the dominant characteristic of this period, not just a few big drops in prices. In many ways, this is more like the behavior of market indexes during the Great Depression, when there were prolonged periods of high volatility, than the brief episodes of volatility that surrounded the October 1987 crash (see Schwert (1990a, 1990b) for comparison).

\section{World Stock Market Conditions}

As a final check on the conclusion that the recent episodes of Nasdaq volatility have been concentrated in the technology sector, figure $12 \mathrm{a}$ shows the historical volatility of the MorganStanley Capital International (MSCI) World portfolio from January 1980 through July 25, 2001. Figure 12b shows volatility of the MSCI World portfolio from January 1995 through July 25, 2001 on the same scale. 
Several things are apparent from figures $12 \mathrm{a}$ and $12 \mathrm{~b}$. First, the recent volatility of the world portfolio is small by comparison with the 1987 market crash, where the volatility estimate peaked at over $60 \%$. Second, the volatility associated with the mid-1998 Japanese and Russian crises, which was followed by the collapse of Long-term Capital Management, was substantially higher than what occurred in most of 1999 and 2000. This is a stark difference from the behavior of the Nasdaq technology stocks shown above, so the explanation for the behavior of the Nasdaq stocks cannot be related to general market conditions.

\section{Conclusions}

Are there any policy implications from the recent episodes of volatility in the technology sector of the market?

\section{An Impeding Recession?}

At the aggregate level, there is much evidence that stock volatility is a leading indicator for economic activity, with heightened volatility often associated with recessions (see Schwert (1989a, 1989b) and Campbell, Lettau, Malkiel, and Xu (2001) for examples). It is an interesting question whether the extent that the recent growth in Nasdaq volatility foreshadows a dramatic slowdown in the technology sector of the economy. To the best of my knowledge, no one has studied the relation between industrial stock return volatility and real activity in that industry. If there is such a link, the very high recent levels of volatility in the technology sector of the stock market could foreshadow a massive recession in this area of the economy. 


\section{Too Much Leverage?}

In terms of financial regulation, many proposals have arisen in the past in response to perceptions that volatility was "too large." For example, Hardouvelis (1990) suggests increasing margin requirements as a way to discourage investors from trading in stocks. Schwert (1989a, 1989c) and Hsieh and Miller (1990) argue that Hardouvelis finds statistical associations between margin requirements and aggregate volatility because the Fed had increased margin requirements in the past when stock prices fell and that volatility also rose when prices fell, so there is no causal link between the regulatory changes and observed volatility. ${ }^{6}$ It is interesting that despite arguments such as those made by Hardouvelis (who was working at the New York Fed at the time), the Federal Reserve Board has not changed the level of margin requirements since 1974, which strongly suggests that the Fed is skeptical about the efficacy of margin requirements as a policy tool.

\section{$\underline{\text { Too Much Trading? }}$}

Another related theme that has often arisen is that the costs of trading have become too low so that investors can trade in and out of stocks quickly and frequently without bearing substantial transaction costs. Of course, for this to be a problem, it must be that there are lots of "noise traders" taking advantage of this opportunity and their trading influences prices in an important way.

One variant on this theme is that the availability of derivative securities, such as options or futures contracts on individual stocks, or on portfolios of stocks, such as the Nasdaq 100 , allow investors to place large risky bets on the movements of a small subset of stocks. The

\footnotetext{
${ }^{6}$ Also see Kupiec $(1989,1993)$ and Kupiec and Sharpe (1991).
} 
existing evidence, however, shows that volatility of the returns to the underlying security typically declines after the introduction of derivatives trading (e.g., Skinner (1989)). ${ }^{7}$

There has also been much recent discussion about "day trading" by relatively small individual investors and the potential effect of this trading on the volatility of market prices. During the Clinton administration, there were significant advocates for taxes on securities transactions (STTs) to "throw sand in the gears" of financial markets, including Joseph Stiglitz (1989) and Lawrence Summers (with Victoria Summers, 1989), who were the chair of the Council of Economic Advisors and the Secretary of the Treasury, respectively (although not at the time they were advocating securities transactions taxes). There are many reasons to think that STTs are a bad idea and, fortunately, they have never been enacted in the United States. Where they have been enacted, trading typically just moves to another venue with lower transaction costs (see Schwert and Seguin (1993) for a more extensive review of the arguments for and against STTs).

It is well known that trading volume and volatility occur together, and the trading volume of large Nasdaq technology stocks has been high during the period when Nasdaq volatility has been high. It would be naïve, however, to conclude that this association is causal, so that reducing trading by increasing transactions costs would somehow make volatility go away. To the extent that volatility is associated with differences in beliefs, it is not surprising that volume and volatility occur together. See Karpoff (1987) for a survey of the literature linking volume and volatility.

In short, it is not clear to me what the implications of recent Nasdaq volatility are for the macroeconomy. Likewise, it is not clear to me that we need to do anything about it. It is clear to me that these data deserve more study.

\footnotetext{
${ }^{7}$ Also see Edwards (1988), Rubinstein (1988), and Tosini (1988).
} 


\section{References}

Bittlingmayer, George and Thomas W. Hazlett, 2000, DOS Kapital: Has antitrust action against Microsoft created value in the computer industry? Journal of Financial Economics 55, 329-359.

Benveniste, Lawrence M. and Paul A. Spindt, 1989, How investment bankers determine the offer price and allocation of new issues, Journal of Financial Economics 24, 343-362.

Black, Fischer and Myron Scholes, 1973, The pricing of options and corporate liabilities, Journal of Political Economy 81, 637-654.

Bollerslev, Tim, 1986, Generalized autoregressive conditional heteroskedasticity, Journal of Econometrics 31, 307-328.

Brav, Alon and Paul A. Gompers, 1997, Myth or reality? The long-run underperformance of initial public offerings: evidence from venture and nonventure capital-backed companies, Journal of Finance $52,1791-1821$.

Campbell, John Y., Martin Lettau, Burton G. Malkiel, and Yexiao Xu, 2001, Have individual stocks become more volatile? An empirical investigation of idiosyncratic risk, Journal of Finance 56, 143.

Cutler, David M., James M. Poterba, and Lawrence H. Summers, 1989, What moves stock prices? Journal of Portfolio Management, 4-12.

Edwards, Franklin R., 1988, Does futures trading increase stock volatility? Financial Analysts Journal 44, 63-69.

Fleming, Jeff, Barbara Ostdiek, and Robert E. Whaley, 1995, Predicting stock market volatility: A new measure, Journal of Futures Markets 15, 265-302.

French, Kenneth R. and Richard Roll, 1986, Stock return variances: the arrival of information and the reaction of traders, Journal of Financial Economics, 17, 5-26.

French, Kenneth R., G. William Schwert, and Robert F. Stambaugh, 1987, Expected stock returns and volatility, Journal of Financial Economics 19, 3-29.

Hardouvelis, Gikas A., 1990, Margin requirements, volatility, and the transitory component of stock prices, American Economic Review 80, 736-762.

Hsieh, David A. and Merton H. Miller, 1990, Margin regulation and stock market variability, Journal of Finance 45, 3-30.

Ibbotson, Roger G., Jody L. Sindelar, and Jay R. Ritter, 1988, Initial public offerings, Journal of Applied Corporate Finance 1, 37-45.

Ibbotson, Roger G., Jody L. Sindelar, and Jay R. Ritter, 1994, The market's problems with the pricing of initial public offerings, Journal of Applied Corporate Finance 7, 66-74. 
Karpoff, Jonathan M., 1987, The relation between price changes and trading volume: A survey, Journal of Financial and Quantitative Analysis 22, 109-126.

Kupiec, Paul H., 1989, Initial margin requirements and stock returns volatility: another look, Journal of Financial Services Research 3, 287-301.

Kupiec, Paul H., 1993, Futures margins and stock price volatility: is there any link? Journal of Futures Markets 13, 677-692.

Kupiec, Paul H. and Stephen A. Sharpe, 1991, Animal spirits, margin requirements, and stock price volatility, Journal of Finance 46, 717-732.

Loughran, Tim and Jay R. Ritter, 1995, The new issues puzzle, Journal of Finance 50, 23-52.

Lowry, Michelle and G. William Schwert, 2001, IPO market cycles: Bubbles or sequential learning? Journal of Finance forthcoming.

Pagan, Adrian R. and G. William Schwert, 1990, Alternative models for conditional stock volatility, Journal of Econometrics 45, 267-290.

Ritter, Jay R., 1991, The long run performance of initial public offerings, Journal of Finance 46 3-28.

Rubinstein, Mark, 1988, Portfolio insurance and the market crash, Financial Analysts Journal 44, 38-47.

Schwert, G. William, 1989a, Business cycles, financial crises and stock volatility, Carnegie-Rochester Conference Series on Public Policy 31, 83-125.

Schwert, G. William, 1989b, Why does stock market volatility change over time? Journal of Finance 44, 1115-1153.

Schwert, G. William, 1989c, Margin regulation and stock volatility, Journal of Financial Services Research 3, 153-164.

Schwert, G. William, 1990a, Stock volatility and the crash of '87, Review of Financial Studies 3, 77-102.

Schwert, G. William, 1990b, Stock market volatility, Financial Analysts Journal 46, 23-34.

Schwert, G. William, and Paul J. Seguin, 1993, Securities transaction taxes: An overview of costs, benefits and unresolved questions, Financial Analysts Journal 49, 27-35.

Skinner, Douglas J., 1989, Options markets and stock return volatility, Journal of Financial Economics $23,61-78$.

Summers, Lawrence H. and Victoria P. Summers, 1989, When financial markets work too well: A cautious case for a securities transaction tax, Journal of Financial Services Research 3, 261-286.

Stiglitz, Joseph E., 1989, Using tax policy to curb speculative short-term trading, Journal of Financial Services Research 3, 101-115.

Tosini, Paula A., 1988, Stock index futures and stock market activity in October 1987, Financial Analysts Journal 44, 28-37. 


\section{Table 1}

GARCH(1,1) models for Nasdaq and S\&P Stock Return Volatility, January 1986-July 25, 2001

$$
\begin{gathered}
\mathrm{R}_{\mathrm{t}}=\alpha+\varepsilon_{\mathrm{t}}, \quad \varepsilon_{\mathrm{t}} \sim \mathrm{N}\left(0, \sigma_{\mathrm{t}}^{2}\right) \quad \text { [Mean Equation] } \\
\sigma_{\mathrm{t}}^{2}=\mathrm{a}_{0}+\mathrm{a}_{1} \mathrm{D}_{\mathrm{t}}+\phi{\sigma_{\mathrm{t}-1}}^{2}+\theta \varepsilon_{\mathrm{t}-1}^{2} \quad \text { [Variance Equation] }
\end{gathered}
$$

$R_{t}$ is the rate of return to the Nasdaq composite portfolio or the Standard \& Poor's composite portfolio on day t. $\sigma_{t}^{2}$ is the conditional variance of the stock return on day $t$. The variable $\mathrm{D}_{\mathrm{t}}$ equals zero before 1999 and one after, to reflect a change in the level of volatility after 1998 . The

\begin{tabular}{|c|c|c|c|c|c|c|c|c|}
\hline & \multicolumn{4}{|c|}{ Nasdaq Returns } & \multicolumn{4}{|c|}{ S\&P Returns } \\
\hline & (1) & (2) & (3) & (4) & (5) & (6) & (7) & (8) \\
\hline & Coefficient & t-statistic & Coefficient & t-statistic & Coefficient & t-statistic & Coefficient & t-statistic \\
\hline \multicolumn{9}{|c|}{ Mean Equation } \\
\hline Constant, $\alpha$ & 0.00096 & 7.31 & 0.00101 & 7.94 & 0.00067 & 5.21 & 0.00069 & 5.34 \\
\hline \multicolumn{9}{|c|}{ Variance Equation } \\
\hline $\mathrm{a}_{0}$ & 0.0000033 & 4.08 & 0.0000048 & 4.78 & 0.0000014 & 3.12 & 0.0000019 & 3.21 \\
\hline$a_{1}$ & & & 0.0000296 & 3.45 & & & 0.0000028 & 1.88 \\
\hline GARCH, $\phi$ & 0.796 & 21.79 & 0.763 & 17.84 & 0.905 & 34.34 & 0.892 & 28.49 \\
\hline $\mathrm{ARCH}, \theta$ & 0.202 & 3.86 & 0.207 & 3.40 & 0.086 & 2.78 & 0.090 & 2.55 \\
\hline Log- & & & & & & & & \\
\hline likelihood & $12,419.41$ & & $12,435.73$ & & $12,867.21$ & & $12,872.26$ & \\
\hline
\end{tabular}
GARCH $(1,1)$ models are estimated using maximum likelihood and the t-statistics use robust estimates. The sample size is 3,932 days. 


\section{Table 2a}

Largest percentage drops in the Nasdaq Composite portfolio between January 1995-July 2001 in column (1). The corresponding percentage changes (returns) to the S\&P 500, S\&P Technology, Nasdaq Computer, and Nasdaq Biotechnology portfolios are in columns (2) through (5). Columns (6) and (8) contain the implied volatilities for the S\&P 100 (VIX) and Nasdaq 100 (VXN) portfolios from option prices on the CBOE. Columns (7) and (9) contain the changes in the implied volatilities from the prior day, $\Delta \mathrm{VIX}$ and $\Delta \mathrm{VXN}$.

\begin{tabular}{|c|c|c|c|c|c|c|c|c|c|c|}
\hline Rank & Date & $\begin{array}{c}\text { (1) } \\
\text { Nasdaq } \\
\text { Composite } \\
\text { Return } \\
\end{array}$ & $\begin{array}{c}\text { S\&P } 500 \\
\text { Return }\end{array}$ & $\begin{array}{c}(3) \\
\text { S\&P } \\
\text { Technology } \\
\text { Return } \\
\end{array}$ & $\begin{array}{c}\text { (4) } \\
\text { Nasdaq } \\
\text { Computer } \\
\text { Return } \\
\end{array}$ & $\begin{array}{l}\quad(5) \\
\text { Nasdaq } \\
\text { Biotech } \\
\text { Return } \\
\end{array}$ & $\begin{array}{c}(6) \\
\text { S\&P } \\
\text { Implied } \\
\text { Volatility } \\
\text { VIX } \\
\end{array}$ & $\Delta \mathbf{V I X}$ & $\begin{array}{c}\text { (8) } \\
\text { Nasdaq } \\
\text { Implied } \\
\text { Volatility } \\
\text { VXN } \\
\end{array}$ & $\Delta \mathbf{V X N}$ \\
\hline 1 & April 14, 2000 & $-9.7 \%$ & $-5.8 \%$ & $-7.5 \%$ & $-9.5 \%$ & $-12.4 \%$ & $39.3 \%$ & $5.4 \%$ & $93.2 \%$ & $14.2 \%$ \\
\hline 2 & August 31,1998 & $-8.6 \%$ & $-6.8 \%$ & $-9.3 \%$ & $-10.2 \%$ & $-6.7 \%$ & $48.3 \%$ & $7.4 \%$ & $56.1 \%$ & $7.1 \%$ \\
\hline 3 & April 3, 2000 & $-7.6 \%$ & $0.5 \%$ & $-4.5 \%$ & $-8.4 \%$ & $-4.9 \%$ & $25.7 \%$ & $-1.6 \%$ & $64.5 \%$ & $2.9 \%$ \\
\hline 4 & January 2, 2001 & $-7.2 \%$ & $-2.8 \%$ & $-6.5 \%$ & $-8.7 \%$ & $-5.9 \%$ & $34.2 \%$ & $4.0 \%$ & $85.0 \%$ & $0.3 \%$ \\
\hline 5 & December 20, 2000 & $-7.1 \%$ & $-3.1 \%$ & $-7.4 \%$ & $-8.7 \%$ & $-7.1 \%$ & $35.7 \%$ & $5.0 \%$ & $89.6 \%$ & $10.8 \%$ \\
\hline 6 & April 12, 2000 & $-7.1 \%$ & $-2.2 \%$ & $-6.7 \%$ & $-7.5 \%$ & $-4.7 \%$ & $31.9 \%$ & $2.9 \%$ & $79.2 \%$ & $5.6 \%$ \\
\hline 7 & October 27, 1997 & $-7.0 \%$ & $-6.9 \%$ & $-7.7 \%$ & $-7.6 \%$ & $-8.0 \%$ & $40.0 \%$ & $13.9 \%$ & $41.5 \%$ & $10.2 \%$ \\
\hline 8 & March 12, 2001 & $-6.3 \%$ & $-4.3 \%$ & $-6.1 \%$ & $-6.8 \%$ & $-12.2 \%$ & $35.1 \%$ & $5.8 \%$ & $76.3 \%$ & $5.5 \%$ \\
\hline 9 & January 5, 2001 & $-6.2 \%$ & $-2.6 \%$ & $-6.4 \%$ & $-7.2 \%$ & $-8.4 \%$ & $32.0 \%$ & $2.1 \%$ & $82.8 \%$ & $9.4 \%$ \\
\hline 10 & April 3, 2001 & $-6.2 \%$ & $-3.4 \%$ & $-6.3 \%$ & $-7.4 \%$ & $-5.2 \%$ & $39.3 \%$ & $4.6 \%$ & $75.1 \%$ & $2.9 \%$ \\
\hline 11 & March 28, 2001 & $-6.0 \%$ & $-2.4 \%$ & $-7.7 \%$ & $-8.2 \%$ & $-1.8 \%$ & $33.2 \%$ & $2.5 \%$ & $68.4 \%$ & $1.8 \%$ \\
\hline 12 & May 23, 2000 & $-5.9 \%$ & $-1.9 \%$ & $-4.8 \%$ & $-6.5 \%$ & $-5.3 \%$ & $29.3 \%$ & $0.5 \%$ & $72.0 \%$ & $0.8 \%$ \\
\hline 13 & April 10, 2000 & $-5.8 \%$ & $-0.8 \%$ & $-4.0 \%$ & $-5.8 \%$ & $-5.3 \%$ & $28.0 \%$ & $1.1 \%$ & $68.8 \%$ & $2.9 \%$ \\
\hline 14 & May 10, 2000 & $-5.6 \%$ & $-2.1 \%$ & $-5.7 \%$ & $-6.1 \%$ & $-4.1 \%$ & $33.3 \%$ & $1.6 \%$ & $72.6 \%$ & $2.7 \%$ \\
\hline 15 & April 19, 1999 & $-5.6 \%$ & $-2.2 \%$ & $-5.5 \%$ & $-6.9 \%$ & $-7.5 \%$ & $28.6 \%$ & $3.1 \%$ & $46.1 \%$ & $3.0 \%$ \\
\hline 16 & October 25, 2000 & $-5.6 \%$ & $-2.4 \%$ & $-6.9 \%$ & $-5.5 \%$ & $-1.8 \%$ & $29.9 \%$ & $3.7 \%$ & $66.5 \%$ & $5.7 \%$ \\
\hline 17 & January 4, 2000 & $-5.6 \%$ & $-3.8 \%$ & $-5.4 \%$ & $-5.7 \%$ & $-8.3 \%$ & $29.6 \%$ & $5.0 \%$ & $54.4 \%$ & $4.3 \%$ \\
\hline 18 & November 8, 2000 & $-5.4 \%$ & $-1.6 \%$ & $-5.7 \%$ & $-6.8 \%$ & $-2.2 \%$ & $28.3 \%$ & $1.5 \%$ & $64.4 \%$ & $6.0 \%$ \\
\hline 19 & November 10, 2000 & $-5.4 \%$ & $-2.4 \%$ & $-6.1 \%$ & $-6.9 \%$ & $-1.4 \%$ & $32.5 \%$ & $2.9 \%$ & $71.6 \%$ & $4.4 \%$ \\
\hline 20 & March 9, 2001 & $-5.3 \%$ & $-2.5 \%$ & $-6.9 \%$ & $-7.7 \%$ & $0.0 \%$ & $29.4 \%$ & $2.9 \%$ & $70.7 \%$ & $3.1 \%$ \\
\hline 21 & November 28, 2000 & $-5.1 \%$ & $-1.0 \%$ & $-4.5 \%$ & $-5.6 \%$ & $-4.8 \%$ & $30.4 \%$ & $1.4 \%$ & $71.7 \%$ & $3.7 \%$ \\
\hline 22 & November 20, 2000 & $-5.0 \%$ & $-1.8 \%$ & $-3.3 \%$ & $-5.6 \%$ & $-7.4 \%$ & $30.3 \%$ & $2.5 \%$ & $69.2 \%$ & $1.9 \%$ \\
\hline 23 & February 16, 2001 & $-5.0 \%$ & $-1.9 \%$ & $-7.1 \%$ & $-5.9 \%$ & $-3.0 \%$ & $25.1 \%$ & $1.6 \%$ & $64.4 \%$ & $0.9 \%$ \\
\hline 24 & October 5, 1998 & $-4.8 \%$ & $-1.4 \%$ & $-5.0 \%$ & $-6.1 \%$ & $-4.1 \%$ & $44.4 \%$ & $2.1 \%$ & $58.8 \%$ & $4.9 \%$ \\
\hline 25 & October 1, 1998 & $-4.8 \%$ & $-3.0 \%$ & $-5.0 \%$ & $-5.7 \%$ & $-3.7 \%$ & $46.5 \%$ & $4.5 \%$ & $55.0 \%$ & $8.0 \%$ \\
\hline
\end{tabular}


Table 2b

Largest percentage increases in the Nasdaq Composite portfolio between January 1995-July 2001 in column (1). The corresponding percentage changes (returns) to the S\&P 500, S\&P Technology, Nasdaq Computer, and Nasdaq Biotechnology portfolios are in columns (2) through (5). Columns (6) and (8) contain the implied volatilities for the S\&P 100 (VIX) and Nasdaq 100 (VXN) portfolios from option prices on the CBOE. Columns (7) and (9) contain the changes in the implied volatilities from the prior day, $\Delta V I X$ and $\triangle \mathrm{VXN}$.

\begin{tabular}{|c|c|c|c|c|c|c|c|c|c|c|}
\hline Rank & Date & $\begin{array}{c}(1) \\
\text { Nasdaq } \\
\text { Composite } \\
\text { Return } \\
\end{array}$ & $\begin{array}{c}\text { S\&P } 500 \\
\text { Return }\end{array}$ & $\begin{array}{c}(3) \\
\text { S\&P } \\
\text { Technology } \\
\text { Return } \\
\end{array}$ & $\begin{array}{c}(4) \\
\text { Nasdaq } \\
\text { Computer } \\
\text { Return } \\
\end{array}$ & $\begin{array}{l}\quad(5) \\
\text { Nasdaq } \\
\text { Biotech } \\
\text { Return } \\
\end{array}$ & $\begin{array}{c}(6) \\
\text { S\&P } \\
\text { Implied } \\
\text { Volatility } \\
\text { VIX } \\
\end{array}$ & $\Delta \mathbf{V I X}$ & $\begin{array}{c}\text { (8) } \\
\text { Nasdaq } \\
\text { Implied } \\
\text { Volatility } \\
\text { VXN } \\
\end{array}$ & $\Delta \mathbf{V X N}$ \\
\hline 1 & January 3, 2001 & $14.2 \%$ & $5.0 \%$ & $16.8 \%$ & $18.1 \%$ & $6.7 \%$ & $28.7 \%$ & $-5.5 \%$ & $76.0 \%$ & $-9.0 \%$ \\
\hline 2 & December 5, 2000 & $10.5 \%$ & $3.9 \%$ & $10.2 \%$ & $13.0 \%$ & $7.6 \%$ & $26.9 \%$ & $-3.4 \%$ & $68.2 \%$ & $-9.6 \%$ \\
\hline 3 & April 5, 2001 & $8.9 \%$ & $4.4 \%$ & $10.1 \%$ & $11.4 \%$ & $8.4 \%$ & $35.0 \%$ & $-4.1 \%$ & $76.3 \%$ & $-0.1 \%$ \\
\hline 4 & April 18, 2001 & $8.1 \%$ & $3.9 \%$ & $9.7 \%$ & $10.4 \%$ & $7.2 \%$ & $28.5 \%$ & $-1.8 \%$ & $69.7 \%$ & $-3.9 \%$ \\
\hline 5 & May 30, 2000 & $7.9 \%$ & $3.2 \%$ & $7.3 \%$ & $8.2 \%$ & $8.0 \%$ & $26.5 \%$ & $-1.0 \%$ & $67.8 \%$ & $-4.2 \%$ \\
\hline 6 & October 13,2000 & $7.9 \%$ & $3.3 \%$ & $8.6 \%$ & $9.3 \%$ & $4.7 \%$ & $31.0 \%$ & $-4.0 \%$ & $59.7 \%$ & $-6.3 \%$ \\
\hline 7 & October 19, 2000 & $7.8 \%$ & $3.5 \%$ & $9.1 \%$ & $9.4 \%$ & $-0.1 \%$ & $28.2 \%$ & $-4.3 \%$ & $54.3 \%$ & $-8.3 \%$ \\
\hline 8 & December 22, 2000 & $7.6 \%$ & $2.4 \%$ & $7.3 \%$ & $9.1 \%$ & $6.2 \%$ & $31.5 \%$ & $-2.9 \%$ & $79.2 \%$ & $-6.3 \%$ \\
\hline 9 & April 18, 2000 & $7.2 \%$ & $2.9 \%$ & $4.7 \%$ & $7.6 \%$ & $10.6 \%$ & $29.4 \%$ & $-2.8 \%$ & $77.8 \%$ & $-4.9 \%$ \\
\hline 10 & April 25, 2000 & $6.6 \%$ & $3.3 \%$ & $6.1 \%$ & $7.0 \%$ & $5.4 \%$ & $27.1 \%$ & $-3.1 \%$ & $71.1 \%$ & $-6.0 \%$ \\
\hline 11 & April 17, 2000 & $6.6 \%$ & $3.3 \%$ & $9.4 \%$ & $8.3 \%$ & $-1.3 \%$ & $32.2 \%$ & $-7.1 \%$ & $82.7 \%$ & $-10.5 \%$ \\
\hline 12 & June 2, 2000 & $6.4 \%$ & $2.0 \%$ & $4.9 \%$ & $6.0 \%$ & $6.7 \%$ & $24.1 \%$ & $-0.6 \%$ & $58.2 \%$ & $-9.3 \%$ \\
\hline 13 & April 10, 2001 & $6.1 \%$ & $2.7 \%$ & $6.9 \%$ & $7.9 \%$ & $4.4 \%$ & $33.3 \%$ & $-3.4 \%$ & $74.4 \%$ & $-0.8 \%$ \\
\hline 14 & September 8, 1998 & $6.0 \%$ & $5.1 \%$ & $6.2 \%$ & $6.4 \%$ & $9.9 \%$ & $37.1 \%$ & $-7.6 \%$ & $47.1 \%$ & $-4.0 \%$ \\
\hline 15 & December 8, 2000 & $6.0 \%$ & $2.0 \%$ & $4.9 \%$ & $6.1 \%$ & $7.8 \%$ & $26.1 \%$ & $-2.9 \%$ & $65.5 \%$ & $-4.6 \%$ \\
\hline 16 & November 14, 2000 & $5.8 \%$ & $2.3 \%$ & $6.3 \%$ & $7.5 \%$ & $1.5 \%$ & $30.2 \%$ & $-1.7 \%$ & $69.6 \%$ & $-2.6 \%$ \\
\hline 17 & October 31, 2000 & $5.6 \%$ & $2.2 \%$ & $5.3 \%$ & $6.1 \%$ & $4.2 \%$ & $26.0 \%$ & $-1.8 \%$ & $63.9 \%$ & $-4.5 \%$ \\
\hline 18 & November 24, 2000 & $5.4 \%$ & $1.5 \%$ & $4.7 \%$ & $5.8 \%$ & $6.3 \%$ & $29.6 \%$ & $-1.6 \%$ & $71.2 \%$ & $-0.4 \%$ \\
\hline 19 & June 1, 2000 & $5.3 \%$ & $2.0 \%$ & $4.8 \%$ & $6.0 \%$ & $3.7 \%$ & $24.7 \%$ & $-1.8 \%$ & $67.5 \%$ & $-0.6 \%$ \\
\hline 20 & July 12, 2001 & $5.3 \%$ & $2.4 \%$ & $7.1 \%$ & $7.6 \%$ & $-1.4 \%$ & $24.5 \%$ & $-2.5 \%$ & $54.0 \%$ & $-3.2 \%$ \\
\hline 21 & October 9, 1998 & $5.2 \%$ & $2.6 \%$ & $5.8 \%$ & $6.7 \%$ & $5.8 \%$ & $45.7 \%$ & $-2.9 \%$ & $63.1 \%$ & $-10.6 \%$ \\
\hline 22 & September 1, 1998 & $5.1 \%$ & $3.9 \%$ & $6.1 \%$ & $6.8 \%$ & $2.8 \%$ & $39.9 \%$ & $-8.5 \%$ & $48.4 \%$ & $-7.8 \%$ \\
\hline 23 & April 19, 2001 & $4.9 \%$ & $1.3 \%$ & $6.8 \%$ & $7.3 \%$ & $0.2 \%$ & $28.5 \%$ & $0.0 \%$ & $71.8 \%$ & $2.1 \%$ \\
\hline 24 & May 21, 2001 & $4.9 \%$ & $1.6 \%$ & $5.1 \%$ & $6.3 \%$ & $5.6 \%$ & $23.2 \%$ & $-1.0 \%$ & $53.0 \%$ & $-0.1 \%$ \\
\hline 25 & September 3, 1999 & $4.0 \%$ & $2.9 \%$ & $3.9 \%$ & $4.5 \%$ & $4.2 \%$ & $21.4 \%$ & $-4.1 \%$ & $35.1 \%$ & $-2.3 \%$ \\
\hline
\end{tabular}




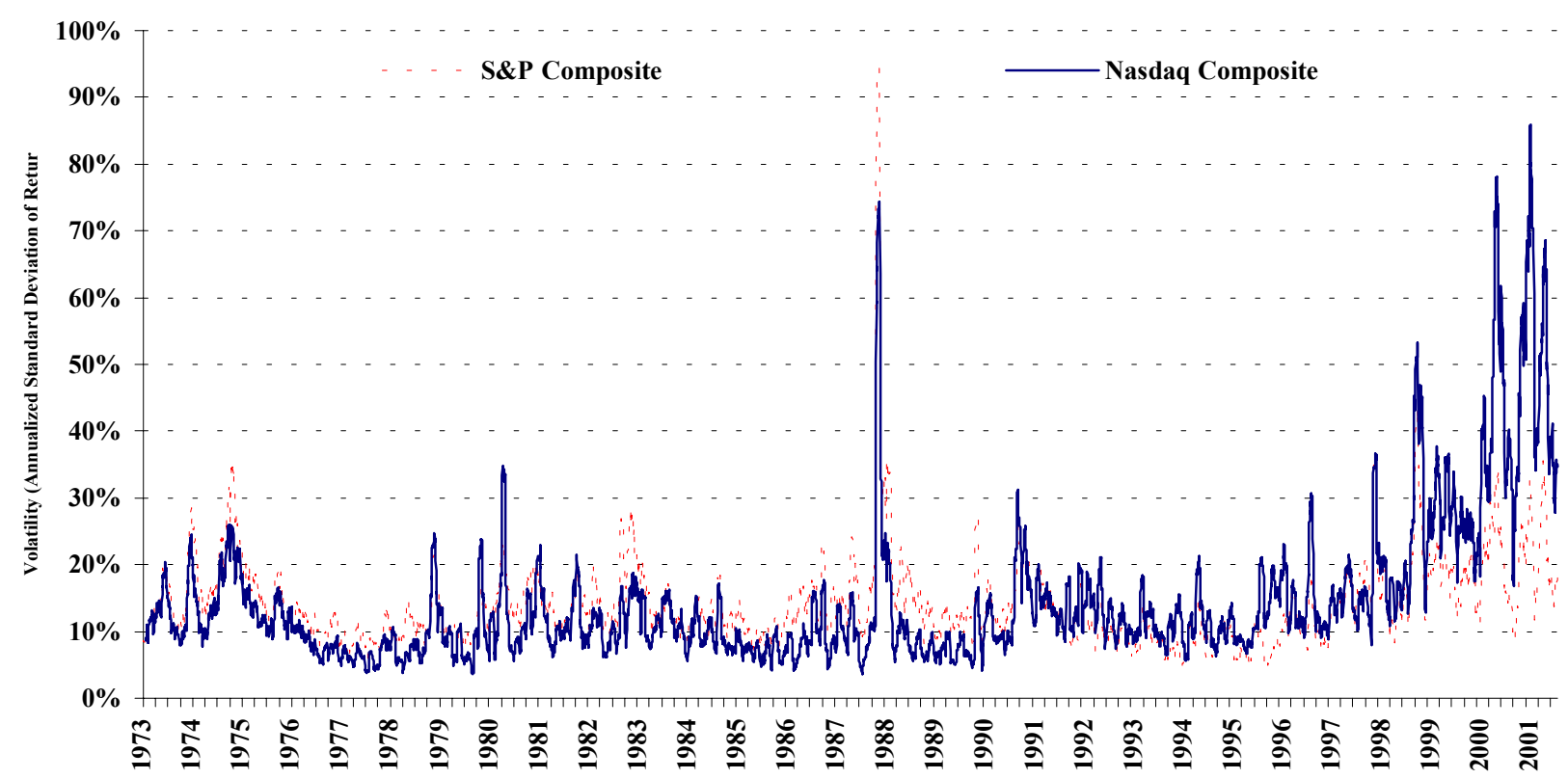

Fig. 1a. Historical volatility of the S\&P and Nasdaq composite portfolios expressed as the annualized standard deviation of the stock return from a rolling 21-day sample, January 1973 through July 25, 2001.

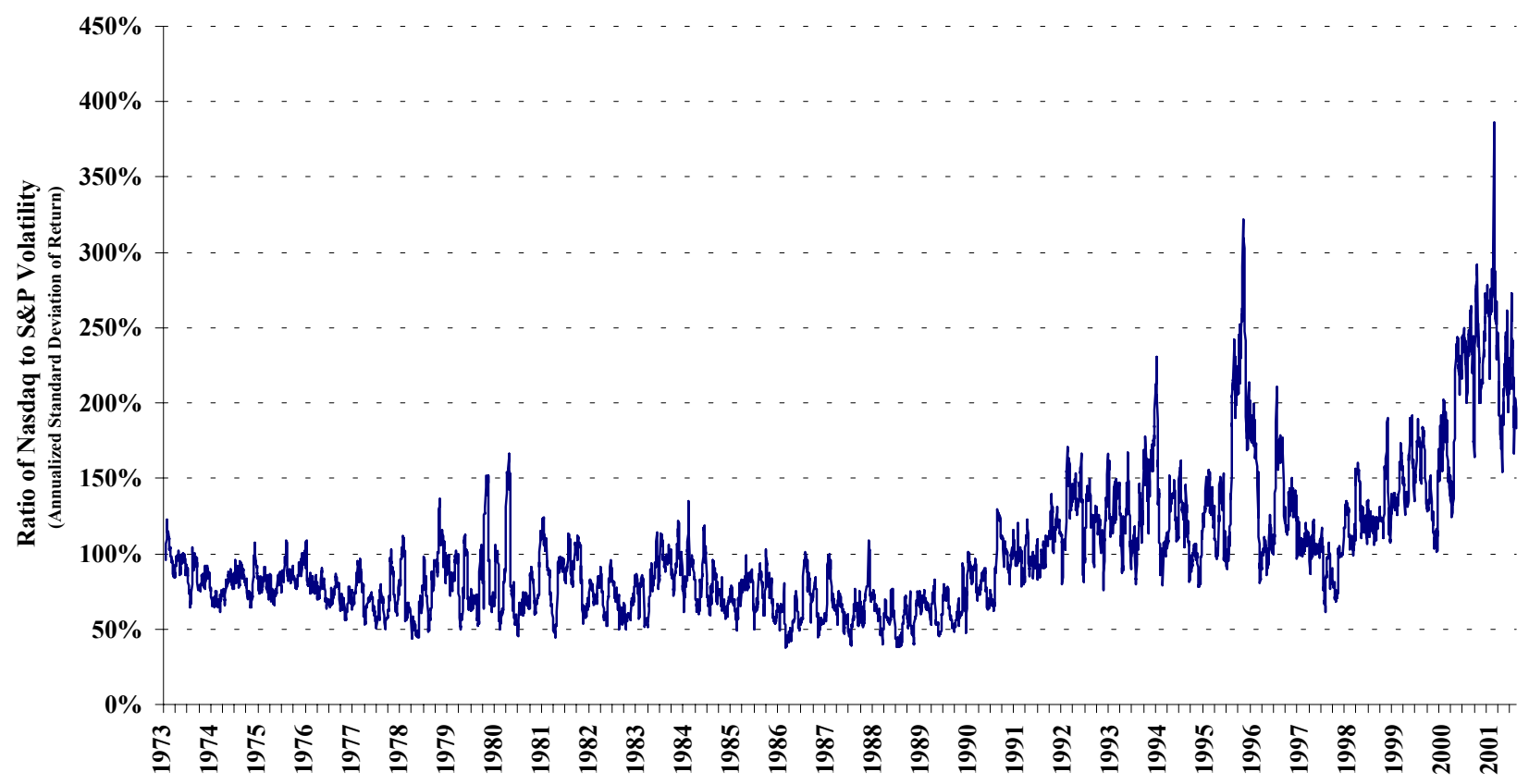

Fig. 1b. Ratio of the historical volatility of the Nasdaq composite portfolio to the volatility of the Standard \& Poor's composite portfolio, January 1973 through July 25, 2001. 


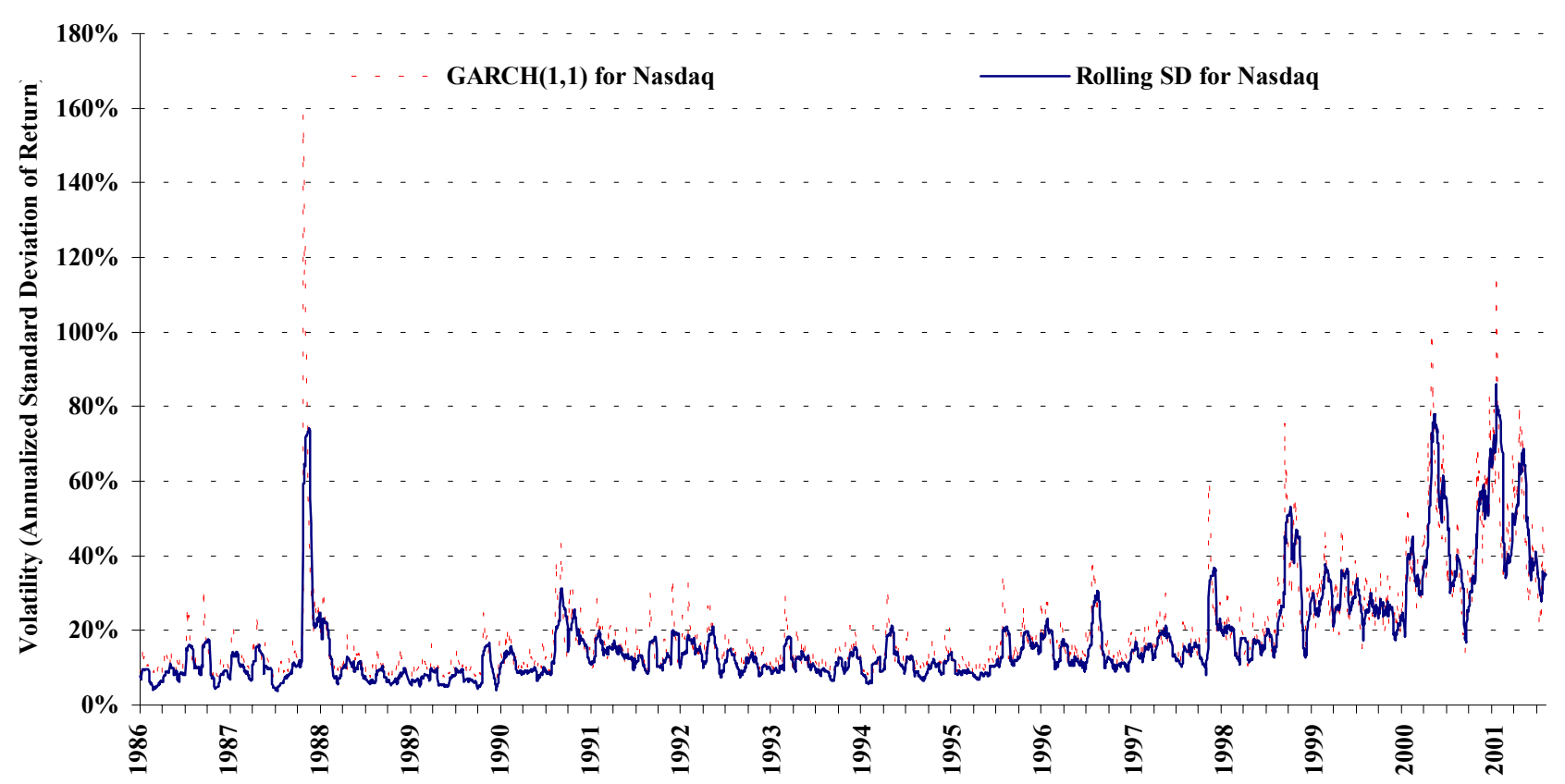

Fig. 2a. Historical volatility of the Nasdaq composite portfolio based on a rolling 21-day standard deviation and estimates of conditional volatility from a GARCH(1,1) model expressed as the annualized standard deviation of the stock return, January 1986 through July 25, 2001.

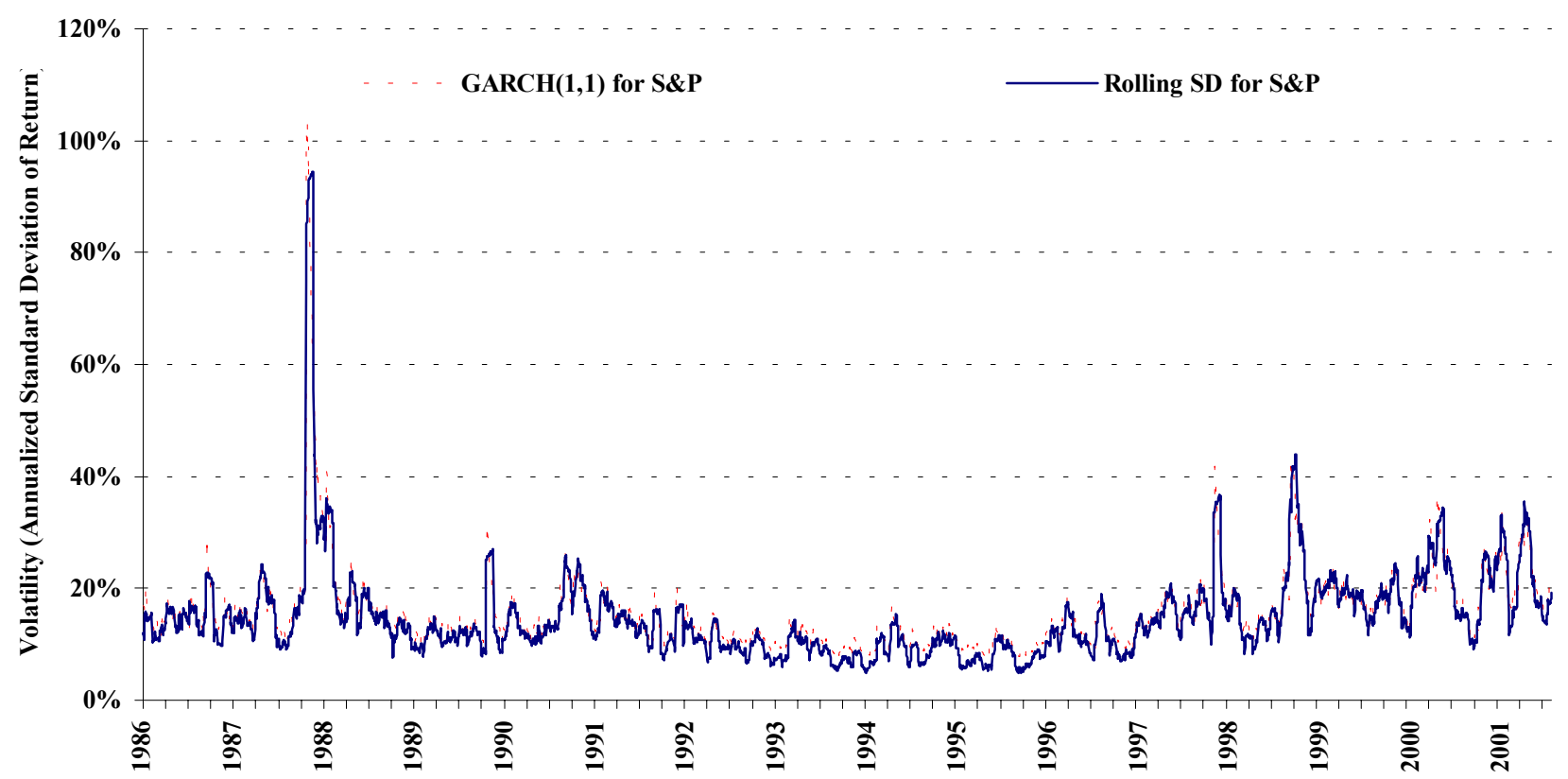

Fig. 2b. Historical volatility of the Standard \& Poor's composite portfolio based on a rolling 21-day standard deviation and estimates of conditional volatility from a GARCH(1,1) model expressed as the annualized standard deviation of the stock return, January 1986 through July 25, 2001. 


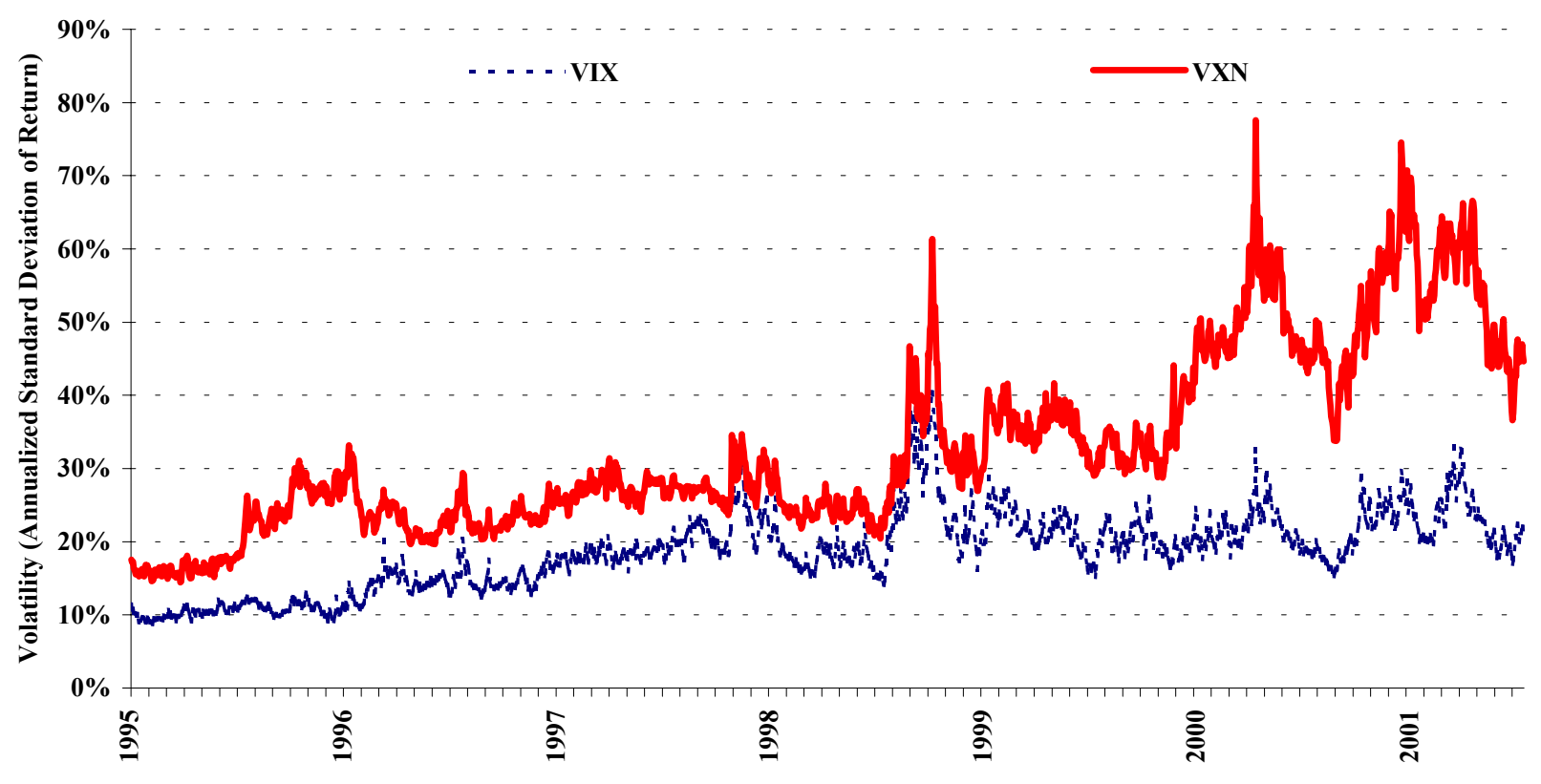

Fig. 3a. Implied volatility of the Standard \& Poor's 100 portfolio (VIX) and of the Nasdaq 100 portfolio (VXN) from CBOE options prices expressed as the annualized standard deviation of the stock return, January 1995 through July 25, 2001.

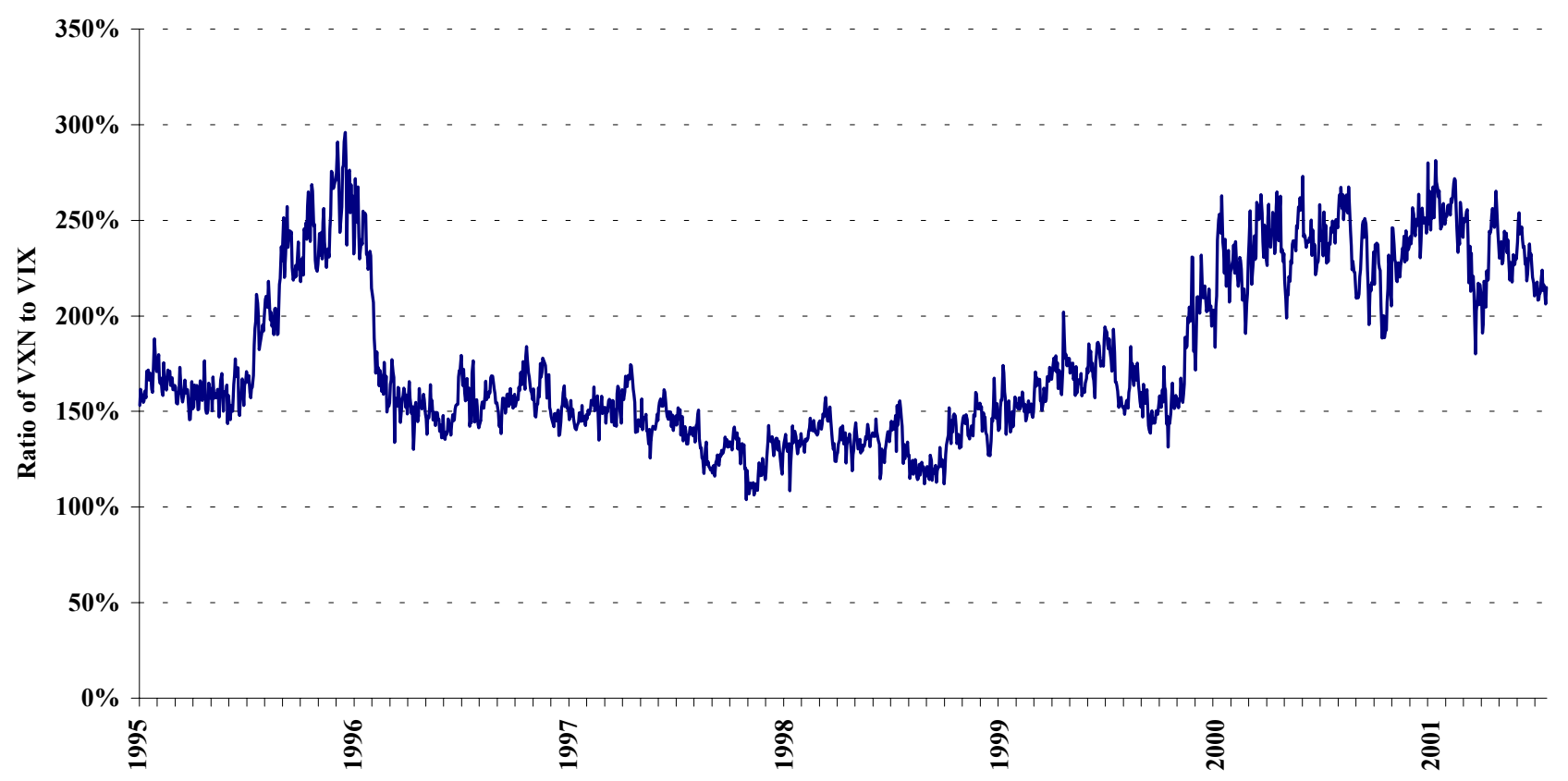

Fig. 3b. Ratio of the implied volatility of the Nasdaq 100 portfolio (VXN) to the implied volatility of the Standard \& Poor's 100 portfolio (VIX), January 1995 through July 25, 2001. 


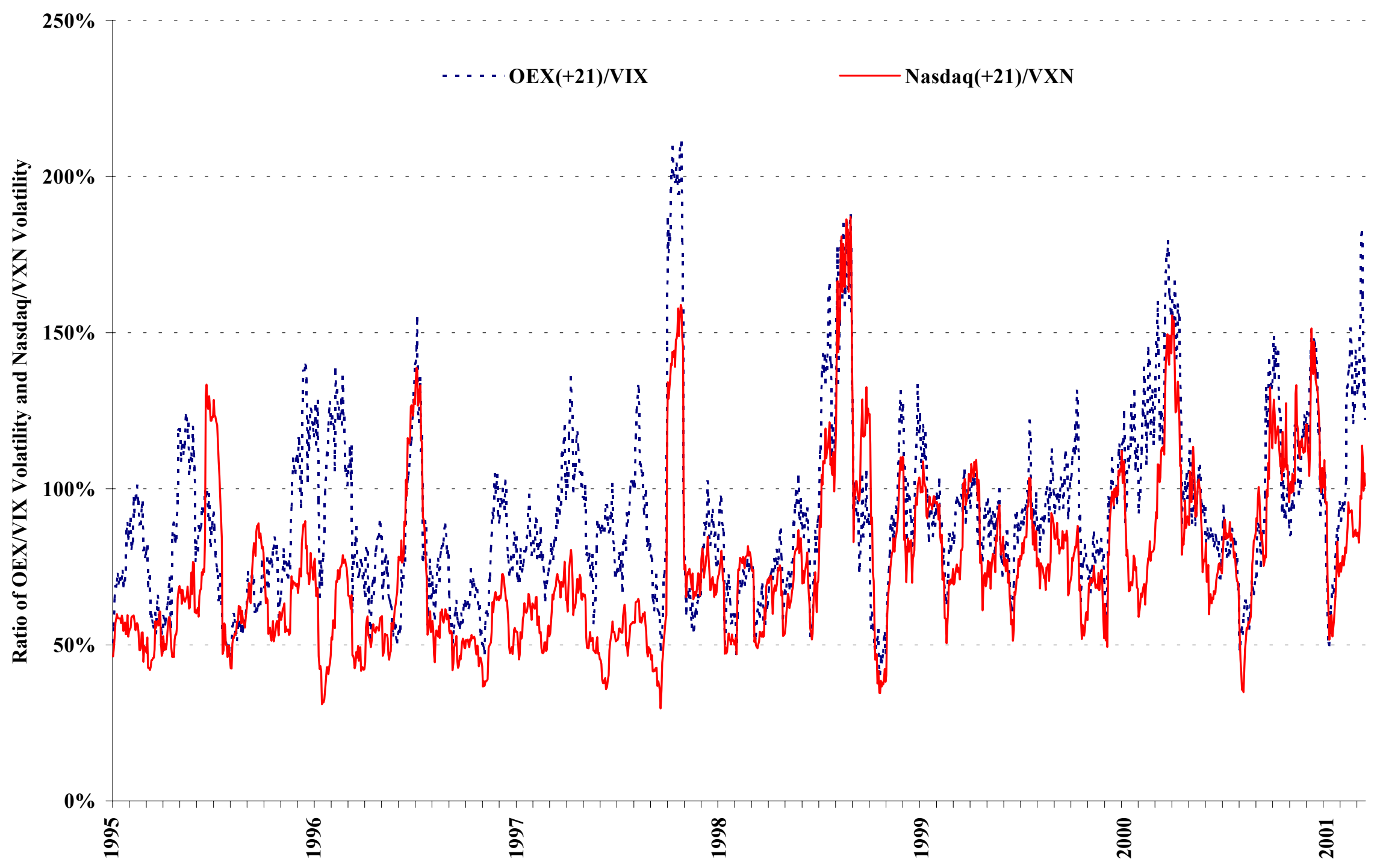

Fig. 4. Ratio of the historical volatility of the S\&P 100 (OEX) portfolio for the next 21 trading days (about one month) to the implied volatility of the S\&P 100 portfolio (VIX) from CBOE options prices. Also, the ratio of the historical volatility of the Nasdaq portfolio for the next 21 trading days to the implied volatility of the Nasdaq 100 portfolio (VXN) from CBOE options prices. January 1995 through June 25, 2001. 


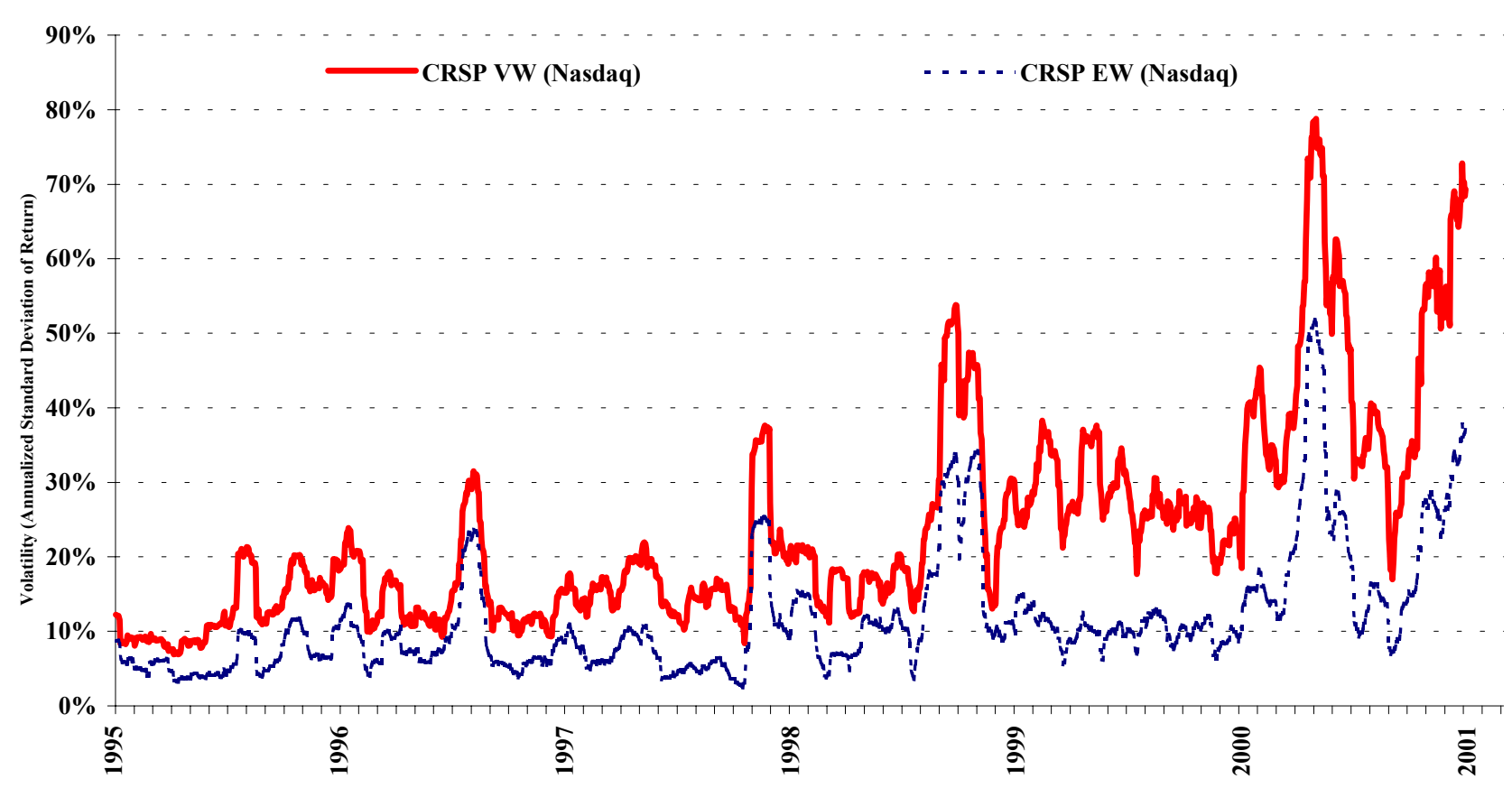

Fig. 5a. Historical volatility of the CRSP Nasdaq value-weighted (VW) and equal-weighted (EW) portfolios, 1995 through 2000.

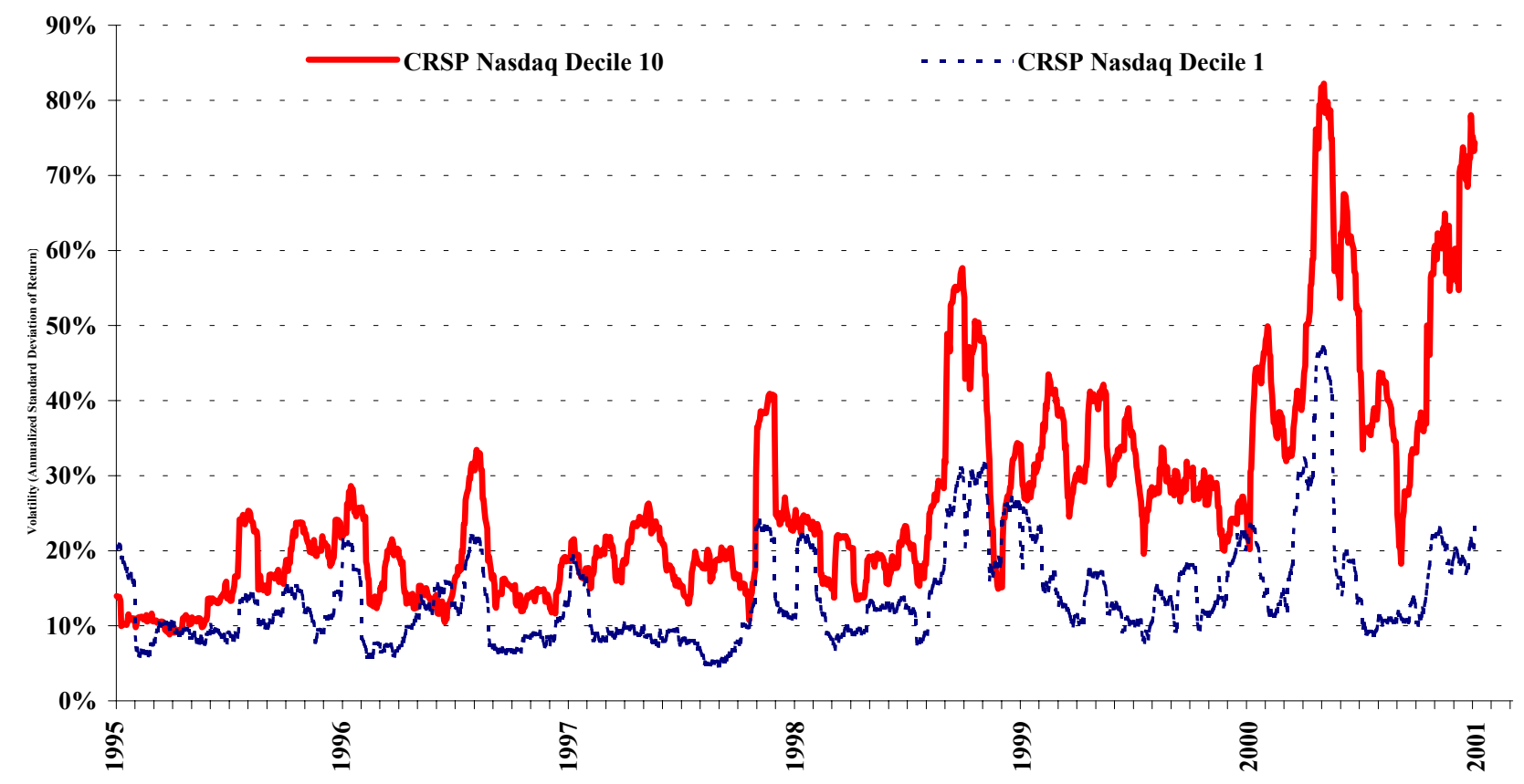

Fig. 5b. Historical volatility of the CRSP Nasdaq large capitalization (decile 10) and small capitalization (decile 1) portfolios, 1995 through 2000. 


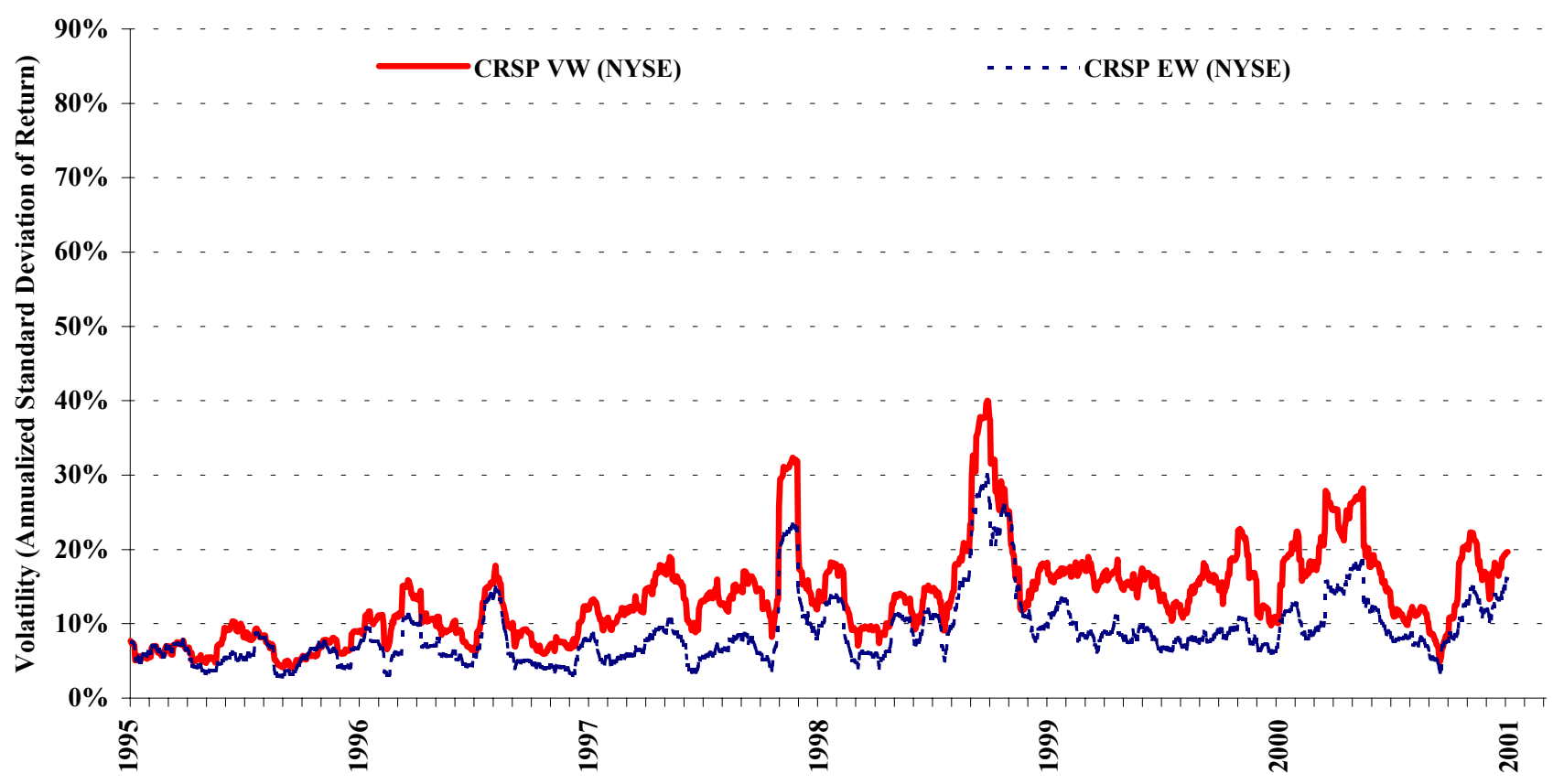

Fig. 6a. Historical volatility of the CRSP NYSE value-weighted (VW) and equal-weighted (EW) portfolios, 1995 through 2000.

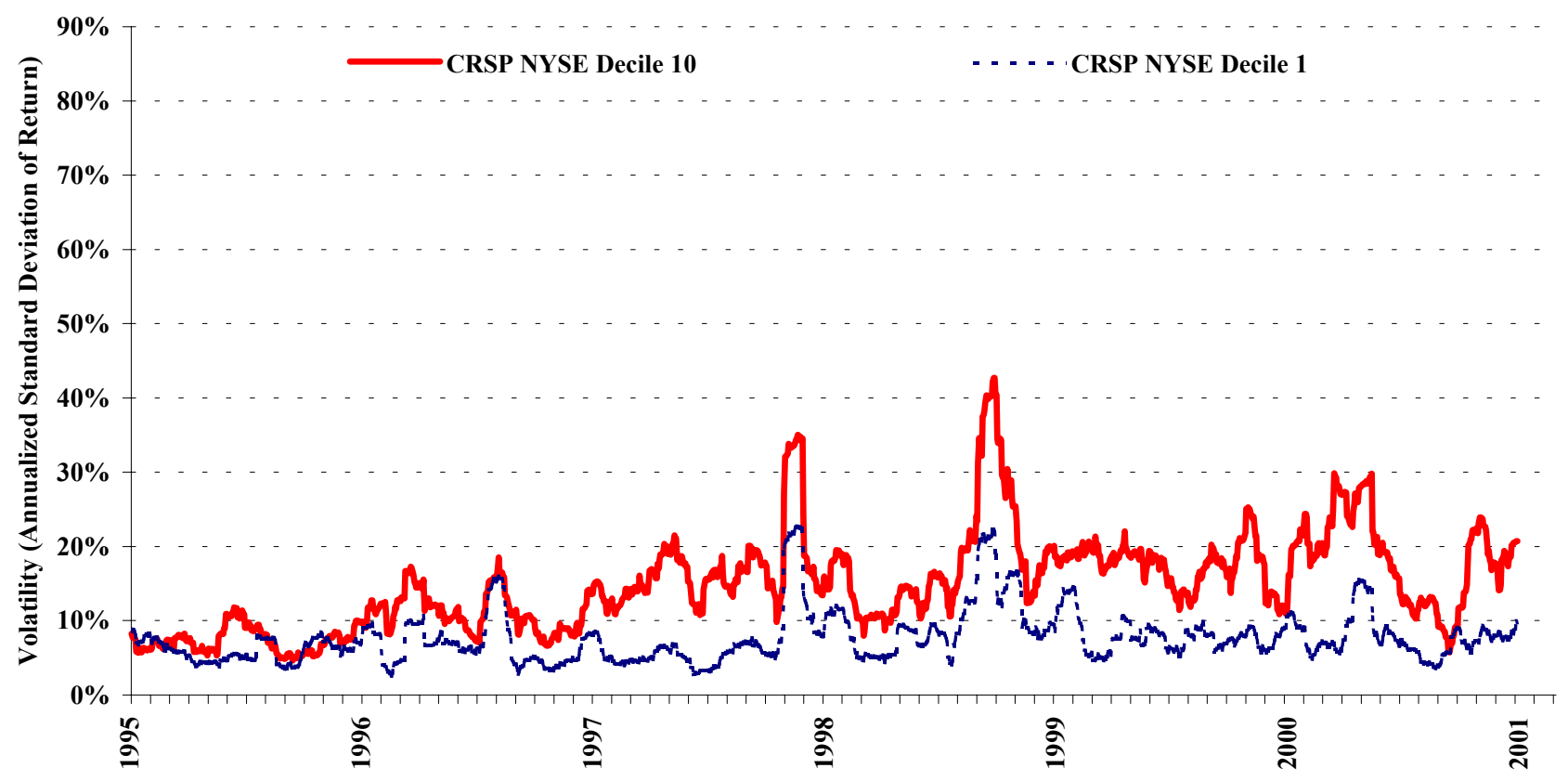

Fig. 6b. Historical volatility of the CRSP NYSE large capitalization (decile 10) and small capitalization (decile 1) portfolios, 1995 through 2000. 


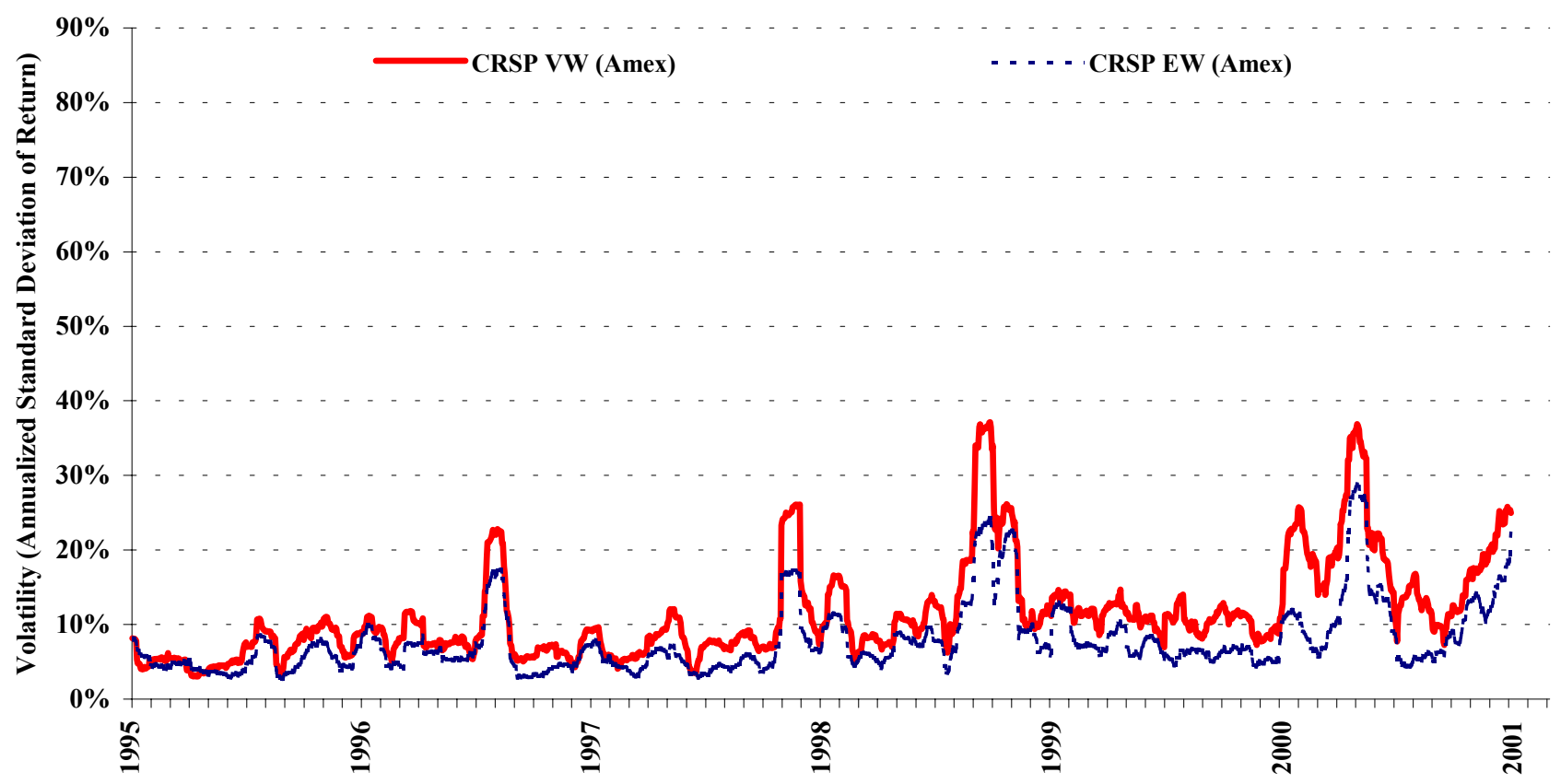

Fig. 7a. Historical volatility of the CRSP Amex value-weighted (VW) and equal-weighted (EW) portfolios, 1995 through 2000.

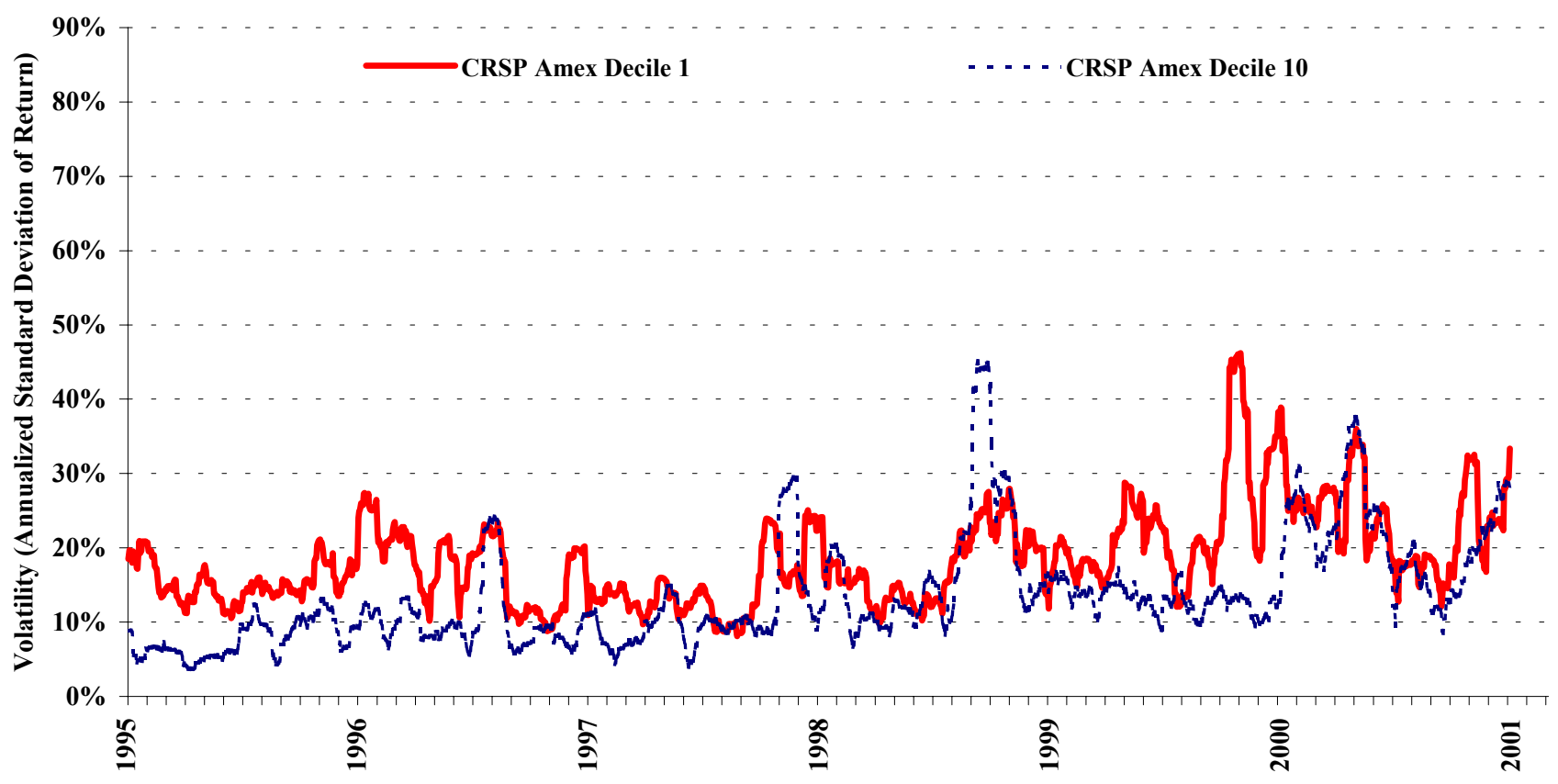

Fig. 7b. Historical volatility of the CRSP Amex large capitalization (decile 10) and small capitalization (decile 1) portfolios, 1995 through 2000. 


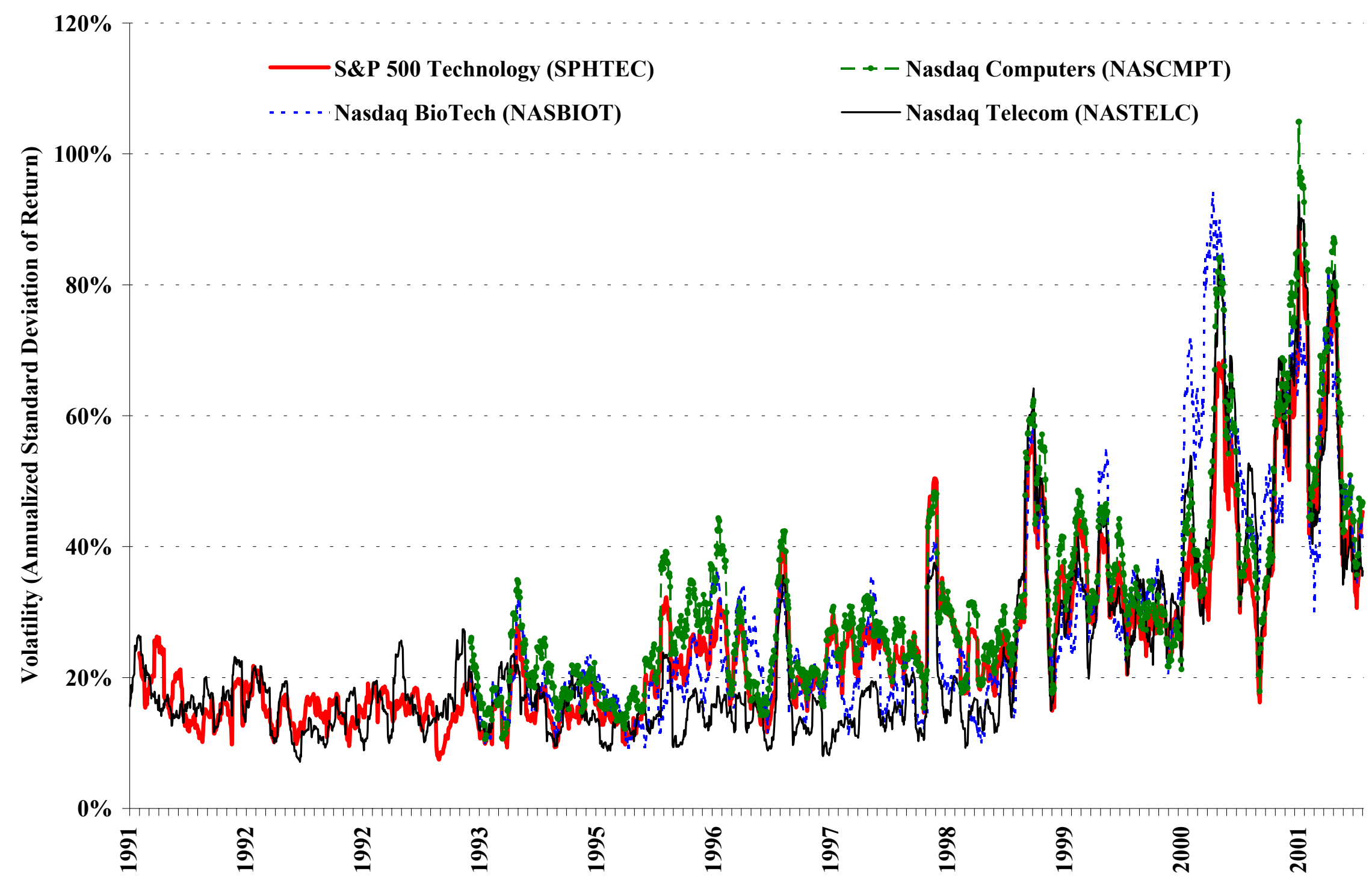

Fig. 8. Historical volatility of the S\&P Technology portfolio (SPHTEC), Nasdaq Computer (NASCMPT), Biotechnology (NASBIOT), and Telecommunications (NASTELC) portfolios, January 1991 through July 25, 2001. 


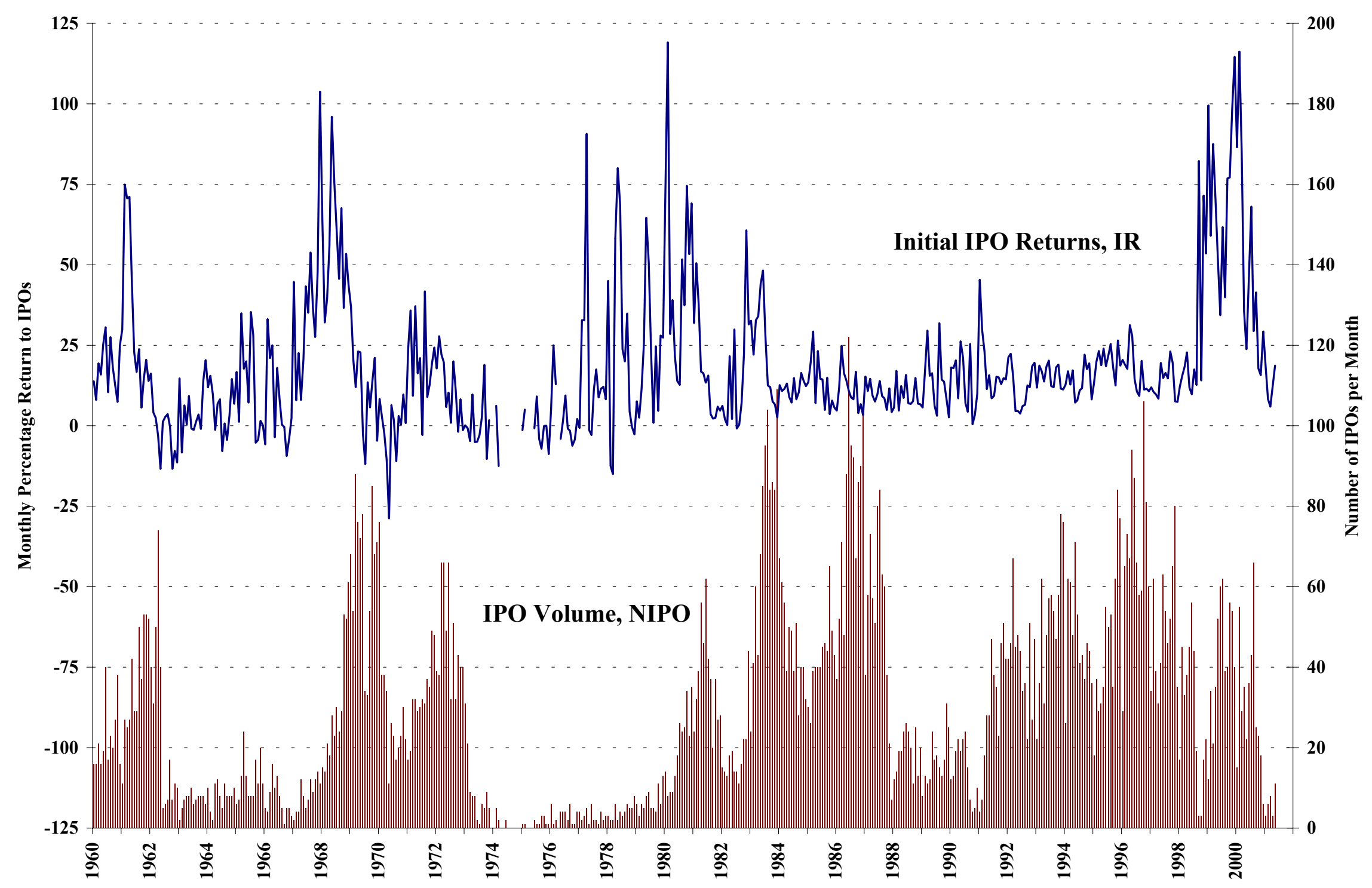

Fig. 9. Ibbotson, Sindelar, and Ritter's (1994) monthly data on aggregate US initial public offerings per month (NIPO) and average initial returns to IPO investors (IR), January 1960 - May 2001, [updated data at http://bear.cba.ufl.edu/ritter/ipoall.htm]. 


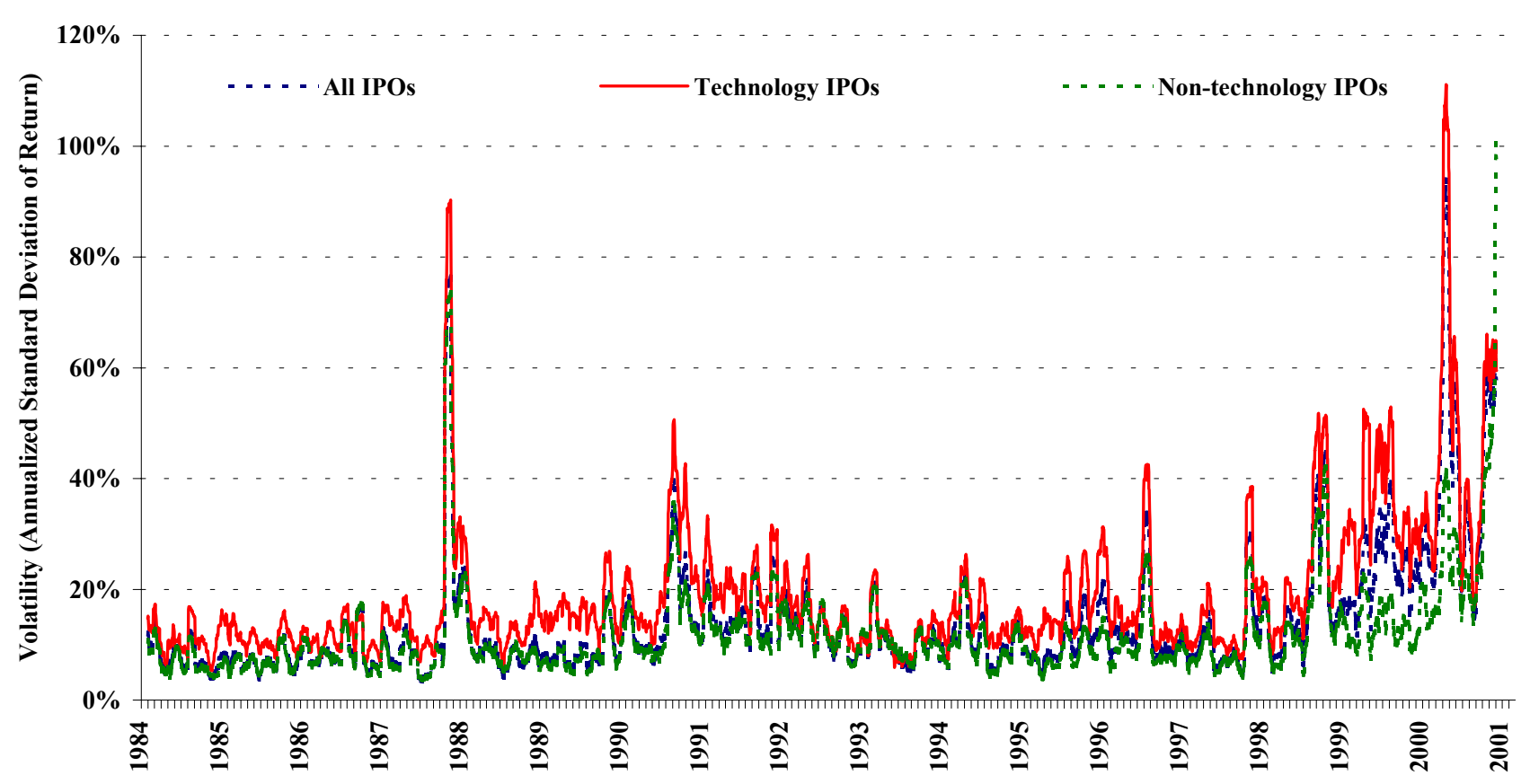

Fig. 10a. Historical volatility of portfolios of firms that recently had IPOs from a rolling 21-day sample, January 1984 through December 2000.

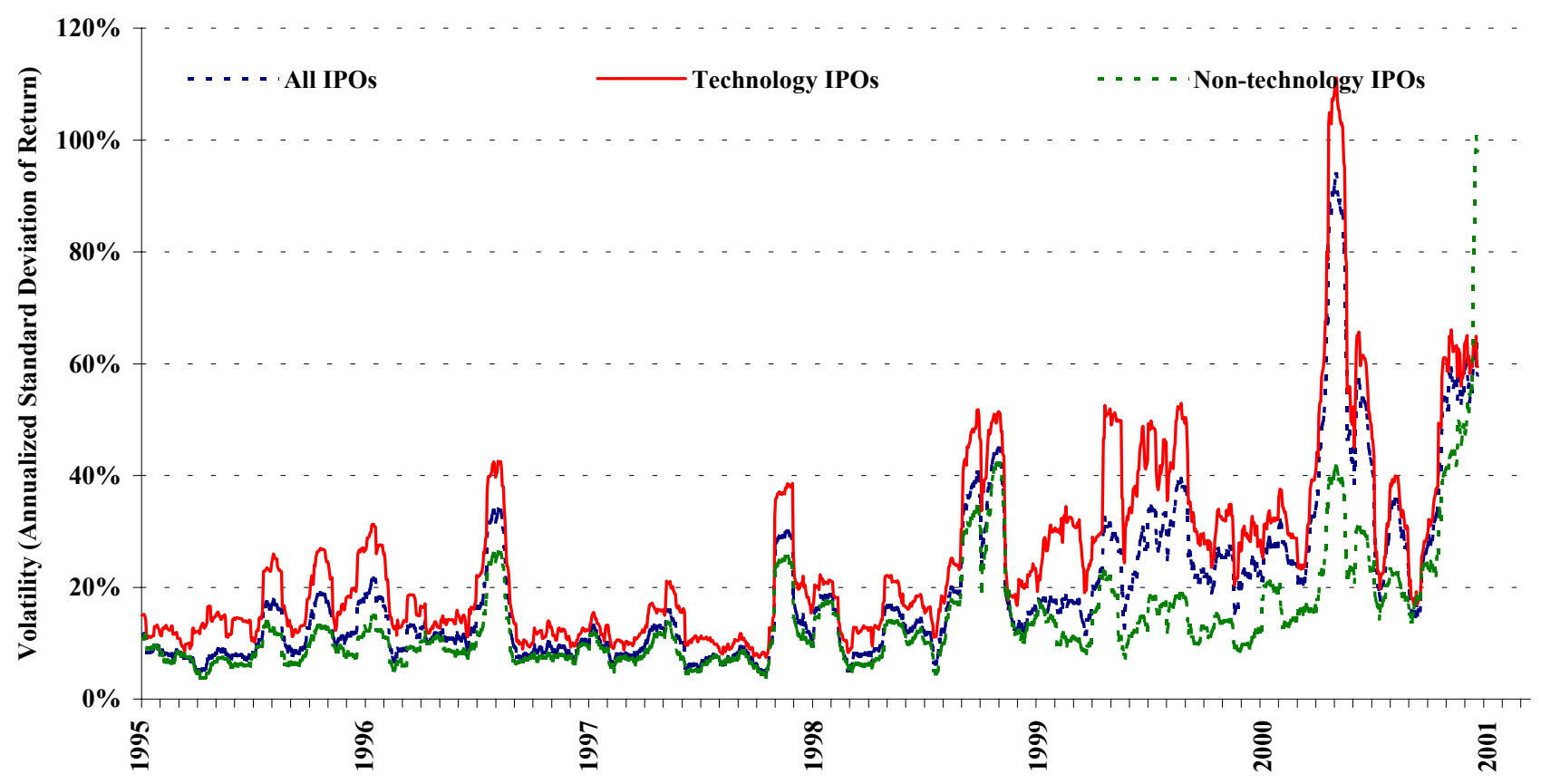

Fig. 10b. Historical volatility of portfolios of firms that recently had IPOs from a rolling 21-day sample, January 1995 through December 2000. 


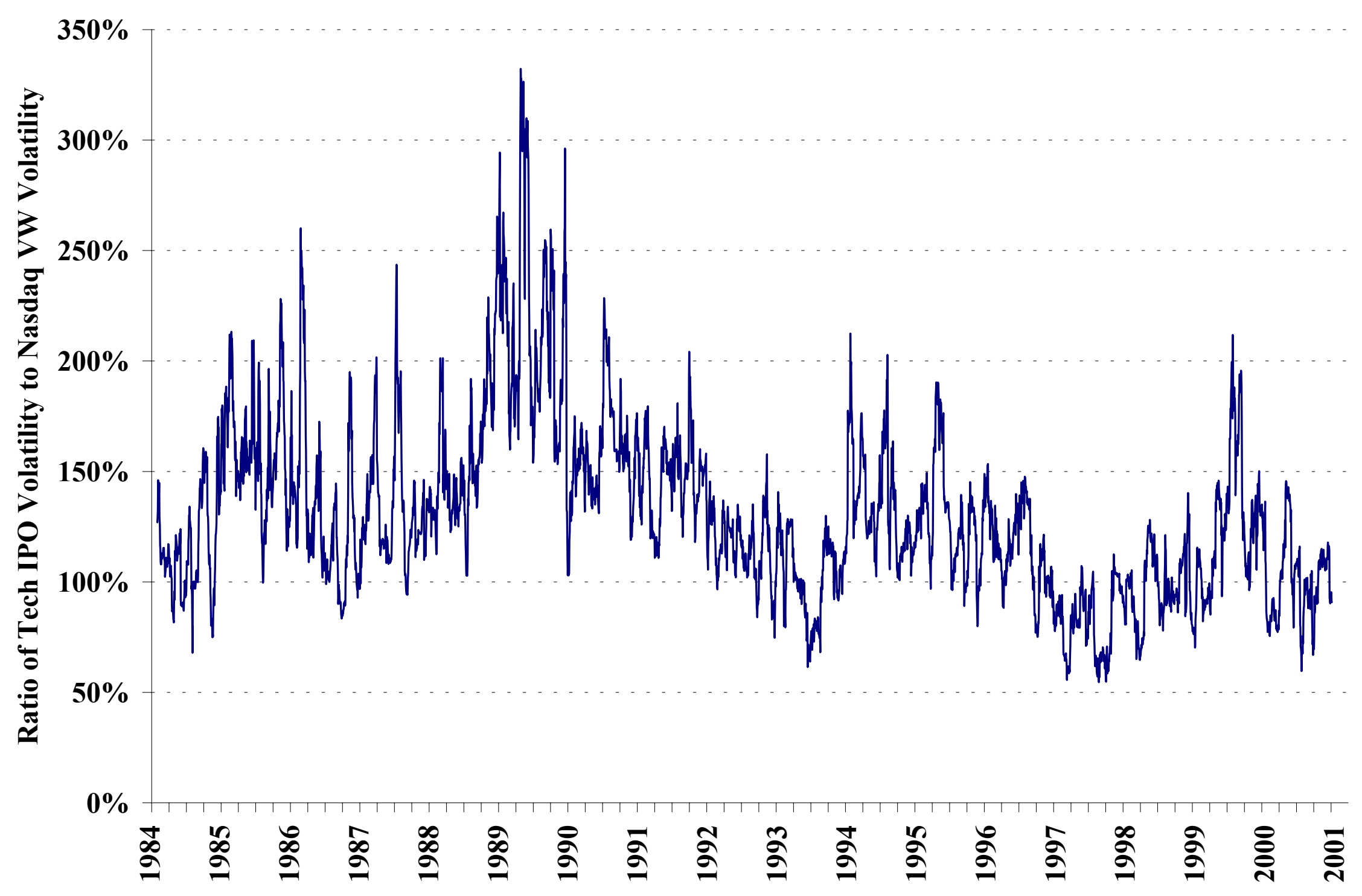

Fig. 11. Ratio of historical volatility of an equal-weighted portfolio of recent Technology IPO stocks to the volatility of the CRSP value-weighted Nasdaq portfolio 1984-2000. 


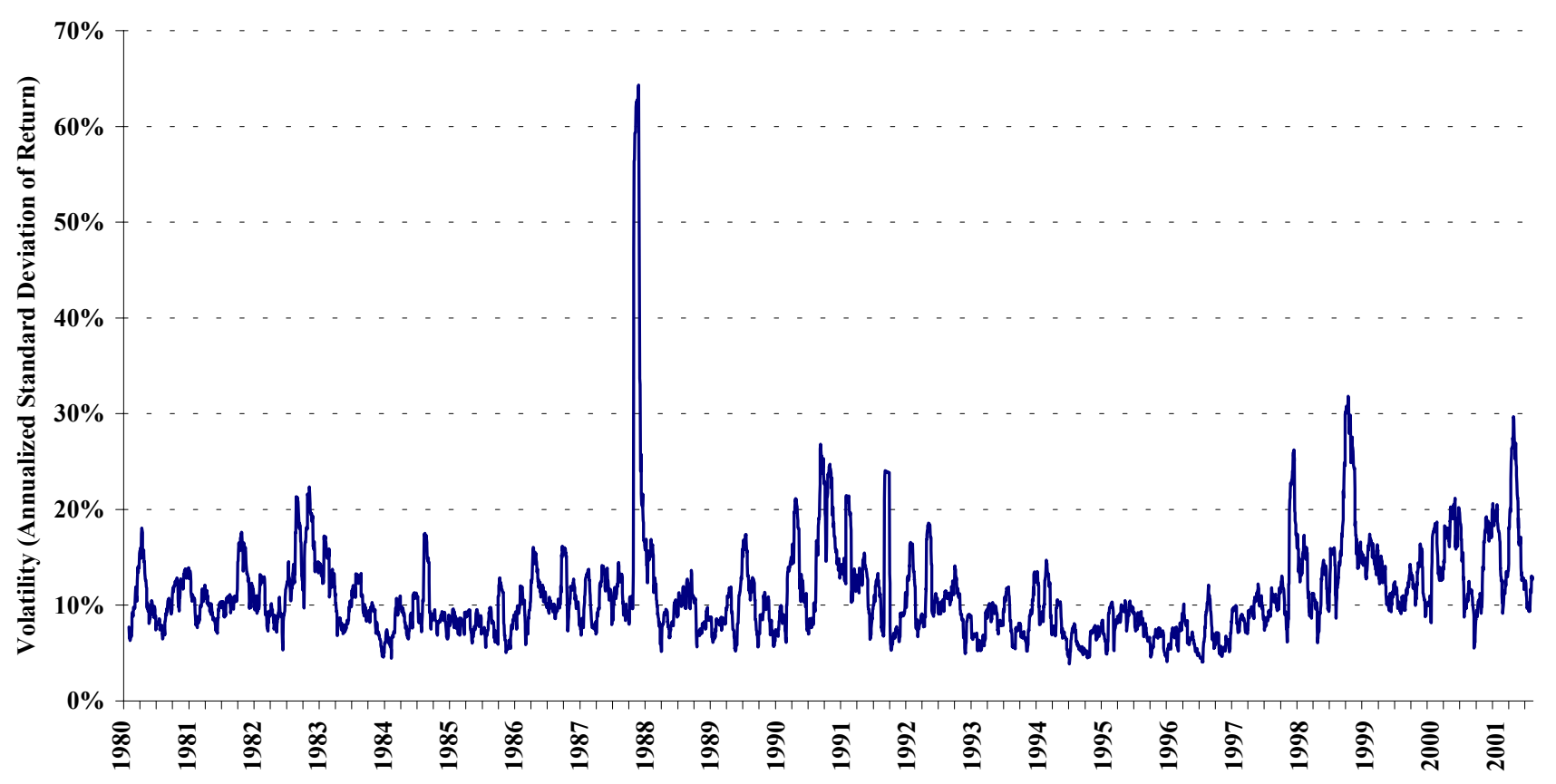

Fig. 12a. Historical volatility of the Morgan-Stanley Capital International World portfolio from a rolling 21-day sample, January 1980 through July 25, 2001.

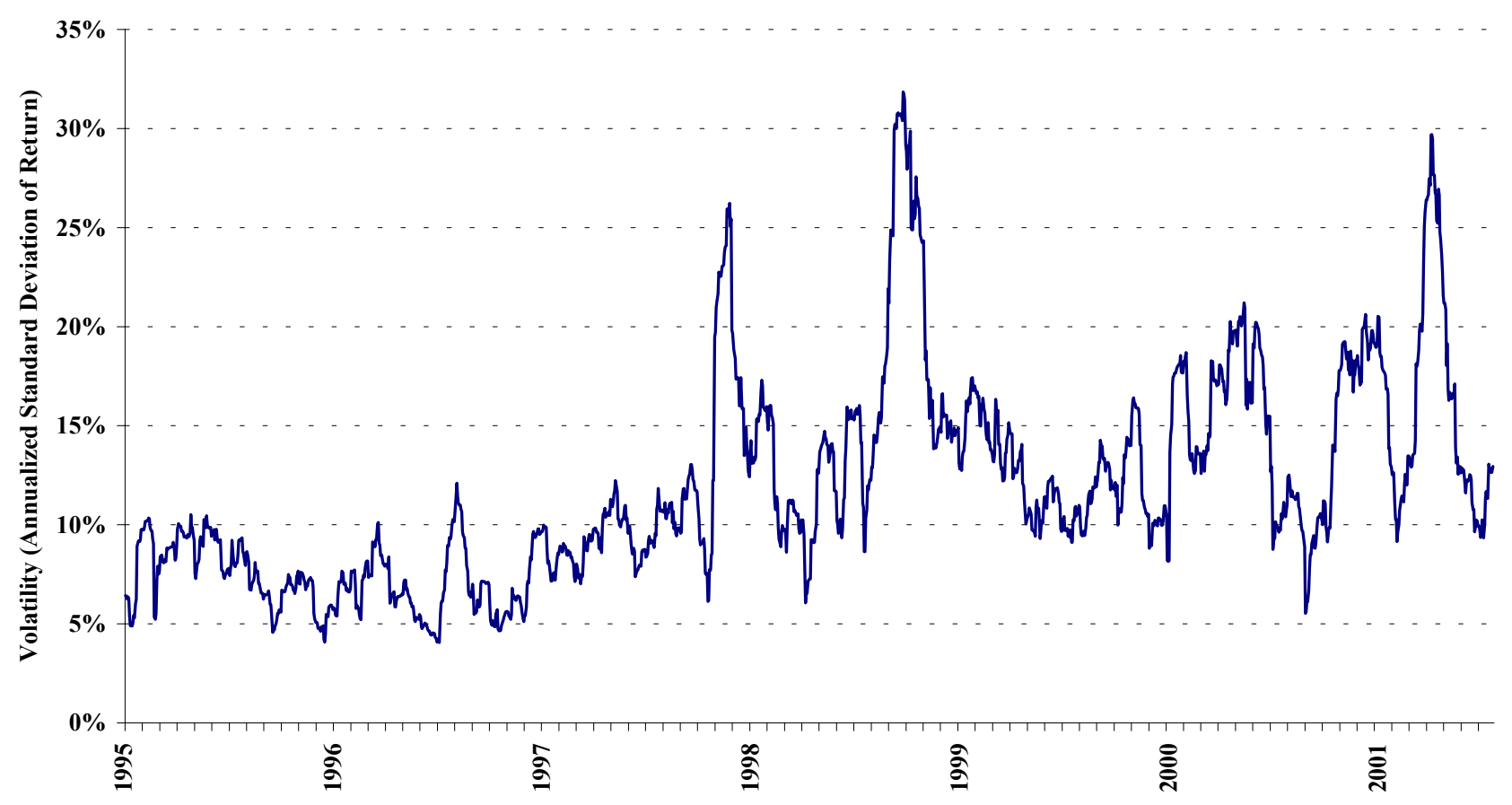

Fig. 12b. Historical volatility of the Morgan-Stanley Capital International World portfolio from a rolling 21-day sample, January 1995 through July 25, 2001. 